\title{
Assessing viability and infectivity of foodborne and waterborne stages (cysts/oocysts) of Giardia duodenalis, Cryptosporidium spp., and Toxoplasma gondii: a review of methods
}

Angélique Rousseau $^{1,2,5}$, Stéphanie La Carbona ${ }^{2, *}$, Aurélien Dumètre ${ }^{3}$, Lucy J. Robertson ${ }^{4}$, Gilles Gargala ${ }^{5}$, Sandie Escotte-Binet ${ }^{1}$, Loïc Favennec ${ }^{5}$, Isabelle Villena ${ }^{1}$, Cédric Gérard ${ }^{6}$, and Dominique Aubert ${ }^{1}$

${ }^{1}$ EA 3800, Protozooses transmises par l'alimentation, Laboratoire de Parasitologie Mycologie, Université de Reims Champagne Ardenne, Faculté de Médecine, SFR Cap Santé Fed 4231, 51 Rue Cognacq Jay, 51096 Reims, France

2 ACTALIA Food Safety Department, 310 Rue Popielujko, 50000 Saint-Lô, France

3 Aix Marseille Univ, IRD (Dakar, Marseille, Papeete), AP-HM, IHU-Méditerranée Infection, UMR Vecteurs - Infections Tropicales et Méditerranéennes (VITROME), Marseille, France

${ }^{4}$ Department of Food Safety and Infection Biology, Faculty of Veterinary Medicine, Norwegian University of Life Sciences, PO Box 8146 Dep., 0033, Oslo, Norway

${ }^{5}$ EA 3800, Protozooses transmises par l'alimentation, Laboratoire de Parasitologie Mycologie, Université de Rouen, 76183 Rouen Cedex, France

${ }^{6}$ Food Safety Microbiology, Nestlé Research Center, PO Box 44, CH-1000 Lausanne 26, Switzerland

Received 22 September 2017, Accepted 9 February 2018, Published online 19 March 2018

\begin{abstract}
Giardia duodenalis, Cryptosporidium spp. and Toxoplasma gondii are protozoan parasites that have been highlighted as emerging foodborne pathogens by the Food and Agriculture Organization of the United Nations and the World Health Organization. According to the European Food Safety Authority, 4786 foodborne and waterborne outbreaks were reported in Europe in 2016, of which $0.4 \%$ were attributed to parasites including Cryptosporidium, Giardia and Trichinella. Until 2016, no standardized methods were available to detect Giardia, Cryptosporidium and Toxoplasma (oo)cysts in food. Therefore, no regulation exists regarding these biohazards. Nevertheless, considering their low infective dose, ingestion of foodstuffs contaminated by low quantities of these three parasites can lead to human infection. To evaluate the risk of protozoan parasites in food, efforts must be made towards exposure assessment to estimate the contamination along the food chain, from raw products to consumers. This requires determining: (i) the occurrence of infective protozoan (oo)cysts in foods, and (ii) the efficacy of control measures to eliminate this contamination. In order to conduct such assessments, methods for identification of viable (i.e. live) and infective parasites are required. This review describes the methods currently available to evaluate infectivity and viability of G. duodenalis cysts, Cryptosporidium spp. and T. gondii oocysts, and their potential for application in exposure assessment to determine the presence of the infective protozoa and/or to characterize the efficacy of control measures. Advantages and limits of each method are highlighted and an analytical strategy is proposed to assess exposure to these protozoa.
\end{abstract}

Key words: Viability, Infectivity, Cryptosporidium, Giardia, Toxoplasma, Risk assessment, Food, Methods

Résumé - Estimation de la viabilité et infectiosité des stades (kystes et oocystes) de Giardia duodenalis, Cryptosporidium spp. et Toxoplasma gondii transmis par la nourriture et l'eau : une revue des méthodes. Giardia duodenalis, Cryptosporidium spp. et Toxoplasma gondii sont des parasites protozoaires qui ont été soulignés comme agents pathogènes émergents dans les aliments par l'Organisation des Nations Unies pour l'alimentation et l'agriculture et l'Organisation Mondiale de la Santé. Selon l'Autorité Européenne de Sécurité des Aliments, 4786 épidémies d'origine alimentaire et hydrique ont été enregistrées en Europe en 2016, dont 0.4\% ont été attribuées à des parasites, incluant Cryptosporidium, Giardia et Trichinella. Jusqu'en 2016, aucune méthode standardisée n'était disponible pour détecter les kystes de Giardia et les oocystes de Cryptosporidium et Toxoplasma dans les aliments. Aucune réglementation n'est donc proposée concernant ces dangers. Cependant, compte tenu de leur faible dose infectieuse, l'ingestion d'une quantité

\footnotetext{
*Corresponding author: s.lacarbona@actalia.eu
} 


\begin{abstract}
d'aliments faiblement contaminés peut entraîner une infection de l'homme. Pour évaluer le risque lié aux protozoaires dans les aliments, des efforts doivent être faits dans l'évaluation de l'exposition pour estimer la contamination le long de la chaîne alimentaire, depuis la matière première jusqu'aux consommateurs. Cette évaluation nécessite de déterminer : (i) la prévalence de parasites infectieux dans les aliments, (ii) l'efficacité des mesures de maîtrise pour éliminer cette contamination. Pour mener une telle évaluation, des méthodes capables d'identifier des parasites viables (vivants) et infectieux sont requises. Cette revue décrit les méthodes actuellement disponibles permettant d'évaluer l'infectiosité et la viabilité des kystes de G. duodenalis et des oocystes de Cryptosporidium spp. et T. gondii, et leur potentiel pour être appliquées dans l'évaluation de l'exposition pour déterminer la présence de parasites infectieux et/ou caractériser l'efficacité des mesures de maîtrise. Les avantages et limites de chaque méthode sont présentés et une stratégie d'analyses est proposée pour évaluer l'exposition à ces protozoaires.
\end{abstract}

\section{Introduction}

Giardia duodenalis and Cryptosporidium spp. are enteric parasites of humans and various other mammals $[205,206]$. Their cysts and oocysts are usually excreted in high numbers in the feces of infected hosts (e.g., up to $10^{9}$ Cryptosporidium oocysts per gram of calf feces) and are immediately infectious upon excretion without requiring a period of development in the environment. Oocysts of the coccidian parasite Toxoplasma gondii are shed exclusively in the feces of felids. One infected cat can excrete millions of non-sporulated oocysts shortly after infection [56]. Oocysts become infectious for humans and other warmblooded animals by sporulation one to five days later, depending on aerobic and temperature conditions [57]. Giardia duodenalis cysts, and Cryptosporidium spp. and T. gondii oocysts can be encountered in different terrestrial and aquatic ecosystems where they can persist for months, possibly years. In addition, these parasites are extremely resistant to many chemical and physical inactivation agents [59]. The cysts and oocysts of these parasites can be transmitted to humans by the fecal-oral route, directly by contact with contaminated hosts (animals or humans depending on the parasites), or indirectly by the waterborne or foodborne routes. Consistent with this, Cryptosporidium spp. and Giardia spp. accounted for the largest waterborne outbreaks reported between 1998 and 2012 in the European Nordic countries, with more than 50,000 persons infected, although Caliciviruses and Campylobacter were the pathogens most frequently involved [95]. Concerning worldwide waterborne outbreaks due to parasitic protozoa, Cryptosporidium spp. and Giardia spp. are the most commonly reported etiological agents [61]. T. gondii oocysts have been responsible for waterborne outbreaks to a lesser extent, being responsible for $2 \%$ of parasitic protozoan outbreaks between January 2004 and December 2010 [16,120]. However, due to the usually non-acute nature of infection with Toxoplasma, the number of waterborne infections associated with this parasite is probably underestimated. In 2016 in Europe, 4786 food-borne outbreaks, including waterborne outbreaks, were reported, of which $0.4 \%$ were due to parasites including Cryptosporidium, Giardia and
Trichinella [60]. However, this number may be underestimated considering the large number of outbreaks where the causative agent remains unknown (36\%). For the foodborne route, fruits and vegetables, in particular those consumed raw or minimally processed, are probably of greatest relevance $[155,175]$. Waters used to irrigate fruits and vegetables can be contaminated by Cryptosporidium spp., G. duodenalis, and T. gondii $[10,39,147,161,207]$. Foods can also be contaminated by oocysts and cysts due to poor hygiene conditions during transformation or preparations, through food handlers, surfaces, or equipment [64,72]. Concerning T. gondii, food transmission is more likely through ingestion of cysts in raw or undercooked meat but this is now considered to be a less predominant source of infection in certain areas or populations [31,201].

The low infectious dose for these protozoan parasites means that the associated risk to public health is increased. The $\mathrm{ID}_{50}$ (number of oocysts required to infect $50 \%$ of exposed people) was estimated to be between 10 and 83 oocysts in healthy adults for C. hominis [40], and $<10$ to 2000 oocysts for different strains of $C$. parvum [170,204]. Similarly, 10 to 100 cysts of G. duodenalis can lead to symptomatic parasitic disease [180]. Giardia and Cryptosporidium infections cause mild to severe recurrent diarrhea or intestinal disorders, and Cryptosporidium is one of the four pathogens involved in most of the cases of diarrhea in children younger than 5 years in low-income countries [130]. For T. gondii, the $\mathrm{ID}_{50}$ is estimated between 1 and 10 oocysts in rodent models [56]. In immunocompetent individuals, infections are usually asymptomatic, resulting in the formation of latent cysts in tissues and organs throughout the body [182]. Infections can, however, sometimes led to severe ocular, cerebral, or multivisceral complications, especially in congenitally infected infants and in immunocompromized people. Along with the immunity status of the host, the genetic type of Toxoplasma is also relevant regarding the development of clinical disease.

Risk assessment in foods includes four components: hazard identification, exposure assessment, hazard characterization, and risk characterization [65]. The oocyst and cyst stages of Cryptosporidium, T. gondii and Giardia 
are now recognized as hazards in some foodstuffs, and data are available concerning their characterization. Efforts should now focus on determining exposure assessment. This step includes the estimation of the presence of infective protozoa and their amounts in foods along the food chain. For Cryptosporidium and Giardia (oo)cysts, exposure assessment is partially addressed through the species/genotypes and genetic assemblages, respectively. Indeed, only some species and/or genotypes of Cryptosporidium spp. are pathogenic in humans [167,174]. For $G$. duodenalis, only assemblages $\mathrm{A}$ and $\mathrm{B}$ are responsible for the vast majority of human infections [206]. In addition to these taxonomic data, information on the infectivity of (oo)cysts is also critical to establish the public health significance of protozoan transmission stages in the environment. However, the Standard Method now available for detection of Cryptosporidium and Giardia in fresh produce [112] is based on immunofluorescence assay microscopy that does not provide this level of information, and neither do other methods that are based on molecular biology detection. These methods have been used to detect these three protozoa in different types of food $[4,105,151]$. Thus, a rapid and efficient method to distinguish infective (oo)cysts from non-infective (oo) cysts is needed for exposure assessment. Although both in vitro and in vivo methods have been developed to evaluate the viability and infectivity of the (oo)cysts of these parasites, currently none of these seem to be suitable for routine application in the water and food industries. In vitro methods include parasite excystation, fluorogenic dye inclusion/exclusion coupled with DNA amplification or not, ability to invade cells and replicate within, reverse transcriptase-polymerase chain reaction (RT-PCR) of specific gene targets, and fluorescence in situ hybridization (FISH). In vivo methods consist of animal infectivity assays.

This paper aims to describe the different methods currently available to determine the infectivity and viability of $G$. duodenalis cysts, and Cryptosporidium spp. and T. gondii oocysts. An infectious Giardia cyst is defined as a viable cyst that is able to release its trophozoites, which can then multiply under appropriate culture conditions. An infectious oocyst of Cryptosporidium spp. or T. gondii is defined as a viable (oo)cyst that is able to excyst and release its sporozoites, which can then infect host cells and differentiate within into a replicative stage. In comparison, a viable (oo)cyst is defined as being alive but not necessarily infective because its trophozoites/sporozoites would fail to replicate in the host or to cause infection in susceptible cells. The implementation of these methods in the framework of exposure assessment in food is also presented according to two main objectives: i) determining the occurrence of infective parasites in naturally contaminated samples; and ii) determining the efficacy of control measures. Advantages and limitations of each method are described in order to propose an analytical strategy to address component three of risk evaluation in foods, i.e. assessing exposure to these infective parasites.

\section{Evaluation of infectivity}

\subsection{Bioassay}

The bioassay method consists of inoculating (oo)cysts into animals in order to observe an infection. This represents the gold standard to study (oo)cyst infectivity. For each parasite, several models and methods are described. However, as well as being extremely expensive, the use of animals raises major ethical concerns that complicate bioassay applications and should be limited.

\subsubsection{Cryptosporidium spp.}

Animal models, including calves, neonatal mice, pigs and lambs, have shown that Cryptosporidium spp. and strains vary in their ability to cause symptomatic infections in various hosts. Models include drug-immunosuppressed and immunodeficient rats [32,179] and mice (SCID, knockout) [21,38,94,156,177,212,230], pigs [101], and gnotobiotic piglets [223,224]. However, the relevance to human infections of infectivity data in animals is unclear. Neonatal mouse models are becoming the reference rodent models for the detection of infectious C. parvum oocysts, allowing the determination of the $\mathrm{ID}_{50}$ or the lowest infectious dose (LID) required to establish infection. Neonatal BALB/c [11,169] and NMRI suckling mice [49,227] are considered the most appropriate models to evaluate $C$. parvum infectivity, but other models have been used (e.g., CD-1/ICR [73] and ARC/Swiss [102]). By standardizing laboratory methods and data analysis, Korich et al. [128] obtained reproducible results in interlaboratory trials using CD-1 neonatal mice. The method to assess infectivity involves quantifying the number of oocysts observed in the intestine [73] or in the feces [103]. In terms of sensitivity, for some experiments and models, a single oocyst can be recognized as infectious using this approach [49,228]. However, because bioassays often use different animals or strains of neonatal mice, different strains of $C$. parvum, and/or different methods to detect the infection, such studies have often produced contradictory results $[188,194]$. Most of the animal models are not susceptible to infection by $C$. hominis or by the other species that sporadically infect humans (particularly immunocompromized individuals) such as C. felis, C. meleagridis, $C$. canis and $C$. cuniculus. The only animal models, to date, for $C$. hominis infection are the gnotobiotic pig model [224,225] and the immunosuppressed Mongolian gerbil model [14]. Mouse models allow identification of infective $C$. parvum oocysts in water and shellfish samples, and have been relatively widely used to determine inactivation efficacy of chemical and physical treatments in a simple matrix, but also in different types of food matrices (beverages and solids) (Table 1).

\subsubsection{Giardia duodenalis}

Few rodent animal models have been described for the evaluation of the infectivity of human isolates of G. duodenalis, i.e. genetic assemblages A and B. These 
Table 1. Methods to determine (oo)cyst infectivity and their application in exposure assessment.

\begin{tabular}{|c|c|c|c|}
\hline \multirow[t]{2}{*}{ Methods } & \multirow[t]{2}{*}{ Parasites } & \multicolumn{2}{|r|}{ Applications } \\
\hline & & $\begin{array}{l}\text { Detection in naturally } \\
\text { contaminated samples }\end{array}$ & Determination of the efficacy of control measures ${ }^{a}$ \\
\hline \multirow[t]{3}{*}{$\begin{array}{l}\text { Bioassays - } \\
\text { Ability of (oo)cysts to } \\
\text { induce infection of } \\
\text { animals }\end{array}$} & $\mathrm{Cp}$ & $\begin{array}{l}\text { River water [210] } \\
\text { Wastewater [109] } \\
\text { Mussels, clams, oysters, } \\
\text { cockles } \\
{[67,69,70,71,88,90,143]}\end{array}$ & $\begin{array}{l}\text { Simple matrix }{ }^{\mathrm{b}} \text { : } \\
\mathrm{H}_{2} \mathrm{O}_{2} \text {-based disinfectants [176] } \\
\text { Chlorine dioxide [198] } \\
\text { Ozone [141,187], ozone }+ \text { monochloramine/ }+ \text { chlorine }[27,28] \\
\text { Salinity: } 10,20 \text { and } 30 \mathrm{ppt} \text { of salt at } 10^{\circ} \mathrm{C} \text { or } 20^{\circ} \mathrm{C}(12 \mathrm{w})[68] \\
\mathrm{UV}[11,46,148,154,187,195,198] \\
\text { US [172] } \\
\text { Pasteurization [99] } \\
\text { Storage } 15^{\circ} \mathrm{C}(9 \mathrm{~m})[115] \\
\text { Storage } 4{ }^{\circ} \mathrm{C} \text { and } 10^{\circ} \mathrm{C}(8 \mathrm{w})[142] \\
\text { Storage }-10^{\circ} \mathrm{C} \text { to }+35^{\circ} \mathrm{C}(24 \mathrm{w})[68] \\
\text { Food matrix: } \\
\text { UV - Fresh apple cider [98] } \\
\text { PUV - Raspberries [131] } \\
\text { HHP, e-beam, microwaves - Oysters }[42,43] \\
\text { Heat (steam cooking) - Mussels }[91] \\
\text { Pasteurization - Milk [99] } \\
\text { Storage } 6{ }^{\circ} \mathrm{C}(4 \mathrm{w})-\text { Apple }[150]\end{array}$ \\
\hline & G & $\begin{array}{l}\text { Wastewater }[82,109,140] \\
\text { Raw and chlorinated } \\
\text { drinking water }[111]\end{array}$ & $\begin{array}{l}\text { Simple matrix: } \\
\text { Ozone [74] } \\
\text { UV [37,139,140,154,196] } \\
\text { Gamma irradiation [203] }\end{array}$ \\
\hline & $\mathrm{T}$ & $\begin{array}{l}\text { Water }[12,110,219] \\
\text { Oysters, mussels [63] }\end{array}$ & $\begin{array}{l}\text { Simple matrix: } \\
\text { Chlorine }[222] \\
\text { Ozone }[59,222] \\
\text { UV }[59,220,223] \\
\text { HHP }[145] \\
\text { Gamma-irradiation }[55] \\
\text { Radiofrequency [221] } \\
\text { Storage }-10^{\circ} \mathrm{C} \text { to } 70^{\circ} \mathrm{C} \text { (up to } 54 \mathrm{~m} \text { ) [53] } \\
\text { Food matrix: } \\
\text { HHP }- \text { Raspberries }[146] \\
\text { Storage } 4^{\circ} \mathrm{C} \text { (up to } 8 \mathrm{w} \text { ) - Raspberries and blueberries }[126]\end{array}$ \\
\hline Cell culture infection - & $\mathrm{Cp}$ & $\begin{array}{l}\text { Wastewater [85] } \\
\text { Water }[133,190]\end{array}$ & $\begin{array}{l}\text { Simple matrix: } \\
\text { Chlorine [15,193], Chlorine dioxide [198], MOS [122] }\end{array}$ \\
\hline \multirow[t]{3}{*}{$\begin{array}{l}\text { Ability of (oo)cysts to } \\
\text { invade and infect cells }\end{array}$} & & & $\begin{array}{l}\text { Ozone }[122,187] \\
\mathrm{UV}[83,122,123,186,187,195,198] \\
\text { Heat } 38^{\circ} \mathrm{C} \text { to } 70^{\circ} \mathrm{C}[193] \\
\text { Storage } 15^{\circ} \mathrm{C}(9 \mathrm{~m})[115] \\
\text { Food matrix: } \\
\text { Organic acids and hydrogen peroxide - Fruit juices }[127]\end{array}$ \\
\hline & $\mathrm{Ch}$ & NA & $\begin{array}{l}\text { Simple matrix: } \\
\text { UV }[118]\end{array}$ \\
\hline & $\mathrm{T}$ & NA & $\begin{array}{l}\text { Simple matrix: } \\
\text { Chlorine [218] } \\
\text { Iodophore-based disinfectants, formalin, acidified ethanol [218] } \\
\text { Ozone }[59] \\
\text { UV }[59,223]\end{array}$ \\
\hline
\end{tabular}

a Relevant for water and food industries;

b Simple matrix: water or buffer.

NA: No available data. Cp: C. parvum; Ch: C. hominis; G: Giardia duodenalis; T: Toxoplasma gondii.

$\mathrm{H}_{2} \mathrm{O}_{2}$ : hydrogen peroxide; MOS: mixed-oxidant solution; UV: ultraviolet; PUV: pulsed-ultraviolet; HHP: high hydrostatic pressure; US: ultrasound; m: months; w: weeks. 
assemblages are not naturally able to infect mice and rats $[132,232]$, but inoculation of trophozoites, and not cysts, can still lead to infection of these animals (only neonatal ones, however) [41,137]. Mongolian gerbils appear to be the only model enabling the assessment of cyst infectivity and are also suitable to explore giardiasis symptoms and clinical resistance [18]. In this model, cyst shedding seems discontinuous and infection is usually assessed by determining the presence of trophozoites in the small intestine by microscopy 7 to 10 days after parasite inoculation [2,137]. $G$. duodenalis genetic assemblages A, B and $\mathrm{E}$ have all been used to infect gerbils, although assemblage $\mathrm{E}$ is less virulent [23]. This technique has been applied to evaluate the efficacy of physical (UV and gamma irradiations) and chemical (ozone) treatments on cysts in a simple matrix, and to assess the exposure of humans to infective cysts in naturally-contaminated samples (Table 1 ).

\subsubsection{Toxoplasma gondii}

A review of the relationship between seroprevalence in the main livestock species and presence of T. gondii in meat analyzed the data from studies providing a direct comparison of two or more direct detection methods into a performance matrix [171]. It was clear from this that the cat bioassay performs best, followed by the mouse bioassay. However, the bioassay in cats is performed in very few laboratories because of the difficulty in implementing an assay with considerable associated ethical issues; therefore, Swiss Webster and SCID mice are the main animal models to assess infectivity of T. gondii oocysts $[54,56,119]$, SCID mice being the most sensitive. Mice are tested for T. gondii seroconversion four weeks post-infection and brain preparations are then examined for tissue cysts by microscopy [219]. Such models have been used to evaluate the presence of infective oocysts in water and shellfish samples (Table 1), and to estimate infectivity of oocysts in soil [136]. Bioassays were also successfully used to evaluate the efficacy of different treatments (e.g., oxidants, UV, high hydrostatic pressure) and the impact of storage time and temperatures on the infectivity of oocysts in simple matrices or adhering to the surface of raspberries and blueberries (Table 1).

To summarize, animal models have been reliably used to evaluate the exposure of humans to infective parasites and can be applied to foods. However, these methods suffer from limitations, the major one being ethical concerns, but also definition of a suitable animal model, lack of reliability when low numbers are used, and expense (Table 3). These disadvantages challenge the scientific community to develop and investigate alternative methods to accurately assess infectivity.

\subsection{Cell culture infection}

\subsubsection{Cryptosporidium spp.}

Investigators have turned to cell cultures as a model for Cryptosporidium infection to avoid the problems associated with animal models. Multiple cell lines support
Cryptosporidium replication, and complete life cycle development has been established in several of them $[35,214]$. Human cell lines are of particular interest, since they can support the development of $C$. parvum and $C$. hominis parasites. These cell lines are highly relevant for human infections as oocyst infectivity and dose-response relationships can easily be studied, and some aspects of Cryptosporidium pathogenicity, such as cell damage and barrier permeability, can also be examined. Human enterocytes HCT-8 are currently the model of choice for evaluating oocyst infectivity because they are relatively easy to maintain and support infection with low oocyst numbers [214]. Moreover, the results obtained with HCT-8 cell lines have been shown to have a better correlation with the neonate $\mathrm{BALB} / \mathrm{c}$ and $\mathrm{CD}-1$ mouse models than those obtained with Caco-2 and MDCK cell lines [187,198]. A non-carcinoma, human small intestinal epithelial cell type, named FHs 74 Int has been described as exhibiting higher levels of infection susceptibility compared with other cell types [216]. A recent study described a further cell line (COLO-680N) as a cell-culture platform that is easy-to-handle and enables the long-term sustainable production of infective oocysts at a laboratory scale, and is presumed will provide a valuable tool for viability assessment as well as other investigations [159].

Cell cultures can be inoculated with whole purified oocysts, mixtures of intact and excysted oocysts, and free or purified sporozoites. Numerous studies have tried to improve the success of cell culture assays by pre-activation of oocysts with bile salts [124], improving culture medium composition [122,213], and favoring sporozoite-host cell contact by centrifugation before co-culture [125]. Compared with PCR and RT-qPCR [51,133], fluorescent labeling and enumeration of developing parasitic foci in cell monolayers is one of the simplest and the most reliable ways to assess oocyst infectivity $[117,190,197]$. It has been shown that an electrical impedance-based device is able to provide insights on Cryptosporidium development in HCT-8 cell cultures. By quantifying the magnitude of the impedimetric response, this device can be used as an infectivity sensor as early as $12 \mathrm{~h}$ post-infection [52]. Cell culture assays have been reported to achieve a sensitivity of one single infectious oocyst and are unlikely to be subject to false-positive results [117]. However, no data are available for species other than C. parvum and C. hominis.

Cell-culture assays have been used to assess the exposure of humans to infective Cryptosporidium spp. oocysts in various types of environmental water samples (Table 1), although in the most recent large waterborne outbreaks of cryptosporidiosis, they do not appear to have been applied $[22,50]$. This approach also seems relevant to assess the efficacy of control measures that can be used in food industries (i.e. oxidants, organic acids, heating or storage at $2-8^{\circ} \mathrm{C}$ ) in simple matrices and in fruit juices, but it has not been extensively applied in foods (Table 1 ).

\subsubsection{Giardia duodenalis}

Two studies have described in vitro cell culture of G. duodenalis combined with PCR or RT-PCR assay 
$[8,84]$. However, as Giardia is not an intracellular parasite and can be successfully cultivated in the absence of other cells (i.e., axenic culture), the value of such an assay to assess the infective potential is unclear.

\subsubsection{Toxoplasma gondii}

Toxoplasma gondii parasites can multiply in virtually any nucleated cell types; however, only murine L20B fibroblasts and human foreskin fibroblasts (HFF) cells have been used to determine the impact of UV, oxidants and other chemicals on oocysts in simple matrices, combined with microscopy to detect tachyzoite foci (Table 1). To date, there seems to have been no application of this method to food matrices.

In conclusion, cell culture appears to be a good alternative method to bioassays for those parasites that are intracellular, showing a good correlation with infectivity for both Cryptosporidium and T. gondii oocysts. Thus, this technique has the potential to provide reliable estimates of exposure to infective protozoa from field to fork. Nevertheless, application of this method on complex food matrices has still not been described (Table 3). Due to its shorter time-to-results than bioassays and its reported ability to detect as few as one infective oocyst (C. parvum), this method should be of interest in prospective occurrence investigations. However, for retrospective investigations, when hazards are detected in foods or in case of foodborne outbreaks, more rapid results are essential so that contaminated foods can be removed from the market.

\section{Evaluation of viability}

Evaluation of viability means determining whether (oo)cysts are alive. However, living, intact, metabolically functional (oo)cysts are not necessarily infective, because their trophozoites/sporozoites can fail to cause infection of their hosts. Hence, to obtain a reliable assessment of the exposure of humans to infective parasites, methods to measure viability are of greatest use if they correlate with the results from infectivity assays. If such a correlation is not established, then detection of viable (oo)cysts does not mean that infective parasites are present, and thus any risk may be overestimated. It thus follows, in using such an assay to determine the efficacy of a treatment process, the effectiveness of the process may be underestimated or the process may be wrongly considered non-effective. In contrast, if false negatives are found, or the method has a poor recovery performance, the population of infective (oo)cysts may be underestimated. In these latter cases, the efficacy of a particular process could be overestimated, and the subsequent risk posed to the population underestimated. In terms of food safety, it is generally considered preferable to use an assay that may overestimate the risk (and underestimate process efficacy), than the other way around, as this conservative approach ("worst-case scenario" approach) ensures that the public health risk is minimized.

\subsection{Changes in morphology and physical properties}

Any visible modification in the morphology, wall integrity, and internal content of the cysts and oocysts may indicate a loss of viability at the single parasite level. Cysts and oocysts with shape deformation, openings in their walls, and/or filled with a granular content with no evidence of intact sporozoites (C. parvum and T. gondii) or internal bodies ( $G$. duodenalis), likely represent nonviable parasites that can be observed microscopically [215]. Non-invasive methods have been described to determine the viability of the oocysts and cysts as a function of their size, morphology and surface electric charges. For instance, electrorotation is a qualitative technique that can be used to detect changes in the morphology and physicochemical properties of microorganisms subjected to an electric rotating field. This approach has been successfully used to investigate the viability of C. parvum [86,87] and G. intestinalis [47], and the sporulation state of Cyclospora cayetanensis which is closely related to $T$. gondii [47]. More recently, microfluidic devices have been designed to measure the size and deformability of $C$. parvum and $C$. muris oocysts by force spectroscopy [153]. This method has been reported to reliably discriminate $C$. parvum from $C$. muris oocysts, and viable from heat-killed $C$. parvum oocysts based on the deformability properties of the oocysts. Such methods could be useful for evaluating the viability of $C$. parvum oocysts in environmental samples with low backgrounds, such as drinking water. However, the use of these methods has not yet been widely adopted, if at all, and their use in the framework of exposure assessment in foods has not been investigated. As the structure and physico-chemical properties of (oo)cysts may be modified in the environment, including in food matrices, and following stressing treatments [160], without affecting viability, it seems unlikely that electrorotation and other biophysical methods will develop beyond being research tools.

\subsection{Excystation assays}

It is generally assumed that parasites able to excyst in vitro are viable and likely to be infectious. In order to induce excystation and release of sporozoites (Cryptosporidium and T. gondii) and trophozoites (Giardia), several treatments have been described that are based upon mimicking the conditions that the parasite would encounter in vivo in a susceptible host. Thus, C. parvum oocysts can be incubated at $37^{\circ} \mathrm{C}$ in solutions containing trypsin with or without sodium taurocholate, or surfactants (sodium dodecyl sulfate) $[36,66,178]$, but excystation rates can vary depending on the dose, time and pretreatment temperature [124]. Pre-treating C. parvum oocysts with acidic and sodium hypochlorite solutions can enhance excystation of the sporozoites [36,184]. An excystation assay has also been described for $C$. muris [157]. Due to the additional presence of sporocysts in T. gondii oocysts, sporozoite excystation first requires opening of the oocyst wall, which is usually achieved in 
vitro by physical means (sonication or bead beating), then disruption of the sporocyst wall following incubation in digestive solution containing bile salts [79]. Standard protocols for excystation of Giardia trophozoites from cysts have been available for many decades $[25,26,100,181]$ and tend to use two sequential steps, a low-pH induction step (using, for example, acidified saline solutions at $\mathrm{pH} 2$ 2.7, often supplemented with L-cysteine hydrochloride and glutathione), followed by an excystation step in which the cysts are exposed to a medium such as trypsin in Tyrodes solution at $\mathrm{pH} 8$. Bile supplementation may also be used. However, successful in vitro excystation is assemblage-dependent, and researchers often struggle to achieve excystation when working with non-laboratory adapted field strains [211].

Excystation is measured as the percentage of excysted (oo)cysts determined by phase contrast microscopy, or qPCR assays [173]. In order to differentiate between excystation and "bursting" of the oocysts due to stress, it is important, for Cryptosporidium at least, that active sporozoite ratios are also determined. Sporozoites that have failed to excyst can be visualized inside the oocysts with a DNA binding dye, such as 4', 6-diamidino-2phenylindole (DAPI) [36]. The excystation method requires a large number of purified (oo)cysts, and an insufficient number may occur when investigating naturally contaminated samples. Consistent with this, only one study reported the use of excystation assays to assess exposure to infective $C$. parvum in drinking water (Table 2). In most studies evaluating the impact of oxidants or UV on Cryptosporidium and Giardia (oo) cysts, excystation does not correlate with infectivity assays (Table 2). Indeed, the ability of the parasites to excyst does not necessarily mean that the parasites will complete their development in the host. Thus, excystation methods overestimate the exposure of humans to infective parasites, and treatments that do not kill the parasites but cause them to become no longer infectious to cells, may have their inactivation credit underestimated. However, in contrast, in vitro excystation may also overestimate inactivation efficacy should substantial numbers of viable (potentially infectious) (oo)cysts fail to excyst when subject to a particular protocol, but nevertheless still remain infective for animals [108]. The same overestimation could also occur should excysted sporozoites of $C$. parvum rapidly lose their viability in vitro [152].

To conclude, despite there being a good correlation with the viability measure based on vital dyes exclusion (PI), excystation assays have many limitations and cannot be considered as an appropriate method to assess the risk of infection associated with exposure to parasites detected in food (Table 3).

\subsection{Viability assays using dyes for live and dead cells}

A commonly used approach to assess viability is to use inclusion and exclusion of specific dyes, often known as vital dye assays, as colored markers of viability. The dye inclusion or exclusion can be evaluated by microscopy (fluorescence microscopy, if the dye used is fluorescent). As each cell (or parasite) can be coded individually according to its dye uptake/activation or exclusion, the assay can be applied to individual parasites or low numbers. If large numbers of parasites are used, then flow cytometry or cell sorting can be used [164]. Relatively few experiments have investigated the use of such dyes for investigating the viability of Toxoplasma oocysts, and the double walls of oocysts and sporocysts indicate that uptake of dyes into these oocysts may be more complex. In addition, the characteristic autofluorescence occurring with T. gondii oocysts may act as a confounder [58].

\subsubsection{Dye exclusion methods}

These methods are based on dyes that can penetrate selectively into cells that have lost their membrane integrity and are excluded by live cells, thus these dyes stain parasites that are dead. Dyes that have been used successfully for this assessment include non-fluorescent dyes such as trypan blue [202], and fluorescent dyes such as eosin, ethidium bromide (EB), ethidium monoazide (EMA), propidium monoazide (PMA), and propidium iodide (PI). EB has been extensively used as a DNA intercalating agent, emitting red fluorescence in the dead cells [229], as well as PI. EMA and PMA, both similar to EB and PI respectively, display an azide group, allowing cross-linkage to DNA upon light exposure, but the main limit of EMA is that it can penetrate into intact cells [168].

Trypan blue stain has been used to assess the effect of household disinfectants on protozoan parasites contaminating fresh produce, including Giardia cysts and Cryptosporidium oocysts, with preliminary results supported by infection studies [62]. PI has been successfully applied to assess the viability of $C$. parvum oocysts in such complex food matrices as shellfish [78]. This dye probably remains the most commonly used and thus, only studies referring to PI are reviewed in Table 2. Whereas PI assays have been shown to correlate with in vitro excystation of C. parvum oocysts [36], and have been widely used in studies in which natural die off in the environment is measured, for investigation of the use of oxidants and UV, PI staining of C. parvum and Giardia (oo)cysts in simple matrices tends not to correlate with infectivity (Table 2). This is probably due to the method by which these decontamination treatments interact with the parasite DNA.

One major limitation of dye-exclusion approaches is that a cell can have an intact membrane but will nevertheless be non-viable. Thus, parasites that are nonviable but have an intact membrane will not stain with those dyes. Hence, dye-exclusion technique leads to the overestimation of the exposure of humans to infective parasites and to the underestimation of the efficacy of control measures. 
Table 2. Methods to determine (oo)cyst viability and their application in exposure assessment.

\begin{tabular}{|c|c|c|c|c|c|}
\hline \multirow[b]{2}{*}{ Methods } & \multirow[b]{2}{*}{ Parasites } & \multicolumn{4}{|c|}{ Applications } \\
\hline & & $\begin{array}{l}\text { Detection in } \\
\text { naturally } \\
\text { contaminated } \\
\text { samples } \\
\end{array}$ & $\begin{array}{l}\text { Agreement } \\
\text { with } \\
\text { infectivity } \\
\text { assays } \\
\end{array}$ & $\begin{array}{c}\text { Determination of the efficacy of control } \\
\text { measures }\end{array}$ & $\begin{array}{l}\text { Agreement } \\
\text { with } \\
\text { infectivity } \\
\text { assays } \\
\end{array}$ \\
\hline \multirow{14}{*}{$\begin{array}{l}\text { Excystation } \\
\text { Ability of } \\
\text { trophozoites / } \\
\text { sporozoites to escape } \\
\text { from the cysts / } \\
\text { oocysts after } \\
\text { stimulation }\end{array}$} & \multirow[t]{10}{*}{$\mathrm{Cp}$} & \multirow[t]{10}{*}{ Drinking water [80] } & \multirow[t]{10}{*}{$\mathrm{NA}$} & Simple matrix ${ }^{\mathrm{b}}$ : & \\
\hline & & & & $\mathrm{H}_{2} \mathrm{O}_{2}$-based disinfectants [176] & - \\
\hline & & & & $\begin{array}{l}\text { Chlorine [29], Chlorine dioxide, } \\
\text { Monochloramine [129] }\end{array}$ & - \\
\hline & & & & Ozone $[29,34,73,129]$ & - \\
\hline & & & & Ammonia $[116]$ & - \\
\hline & & & & $\begin{array}{l}\text { Liming, alum and ferric sulfate floccing } \\
\text { [183] }\end{array}$ & NA \\
\hline & & & & UV $[77,89,123,154,158]$ & - \\
\hline & & & & Freezing [183] & NA \\
\hline & & & & Storage at $4{ }^{\circ} \mathrm{C}$ and $10^{\circ} \mathrm{C}(8 \mathrm{w})[142]$ & - \\
\hline & & & & Dessication [183] & NA \\
\hline & \multirow[t]{4}{*}{$\mathrm{G}$} & \multirow{4}{*}{ NA } & \multirow[t]{4}{*}{ NA } & Simple matrix: & \\
\hline & & & & Vinegar (acetic acid $4 \%$ ) à $4^{\circ} \mathrm{C}$ et $21^{\circ} \mathrm{C}$ [45] & NA \\
\hline & & & & UV [84] & - \\
\hline & & & & Storage at $4{ }^{\circ} \mathrm{C}$ (up to $56 \mathrm{~d}$ ) [25] & NA \\
\hline \multirow{13}{*}{$\begin{array}{l}\text { Vital dye-exclusion } \\
\text { (propidium iodide) } \\
\text { Ability of cells to } \\
\text { exclude the dye } \\
\text { (membrane intact } \\
\text { cells) \& staining of } \\
\text { dead cells }\end{array}$} & \multirow[t]{10}{*}{$\mathrm{Cp}$} & $\begin{array}{l}\text { Wastewater }[6] \\
\text { Surface water [190] }\end{array}$ & $\begin{array}{l}\text { NA } \\
-\S\end{array}$ & $\begin{array}{l}\text { Simple matrix: } \\
\mathrm{H}_{2} \mathrm{O}_{2} \text {-based disinfectants }[176]\end{array}$ & - \\
\hline & & Marine water [191] & NA & Chlorine [29] & - \\
\hline & & Drinking water $[6]$ & NA & Ozone $[29,34]$ & - \\
\hline & & Cockles, mussels, & NA & Ammonia [116] & - \\
\hline & & clams $[90]$ & & $\begin{array}{l}\text { Liming, alum and ferric sulfate floccing } \\
\text { [183] }\end{array}$ & NA \\
\hline & & Oysters $[90,191]$ & NA & UV $[77,89,154,158]$ & $+/-$ \\
\hline & & & & Freeze-thaw [121] & NA \\
\hline & & & & Freezing [183] & NA \\
\hline & & & & Storage $4{ }^{\circ} \mathrm{C}$ and $20^{\circ} \mathrm{C}(12 \mathrm{w})[166]$ & NA \\
\hline & & & & Dessication [183] & NA \\
\hline & \multirow[t]{3}{*}{$\mathrm{G}$} & \multirow[t]{3}{*}{$\begin{array}{l}\text { Drinking and } \\
\text { wastewater [6] }\end{array}$} & \multirow[t]{3}{*}{ NA } & $\begin{array}{l}\text { Simple matrix: } \\
\text { UV }[37,84,162]\end{array}$ & - \\
\hline & & & & Gamma radiation [203] & - \\
\hline & & & & Storage $4{ }^{\circ} \mathrm{C}$ (up to $56 \mathrm{~d}$ ) [24] & NA \\
\hline \multirow{13}{*}{$\begin{array}{l}\text { RT-PCR } \\
\text { Ability of cells to } \\
\text { produce mRNA }\end{array}$} & \multirow[t]{10}{*}{$\mathrm{Cp}$} & \multirow[t]{10}{*}{ NA } & \multirow[t]{10}{*}{ NA } & Simple matrix: & \\
\hline & & & & $\mathrm{H}_{2} \mathrm{O}_{2}[h s p 70][144]$ & NA \\
\hline & & & & $\begin{array}{l}\text { Chlorine, Chlorine dioxide, MOS [hsp } 70 \text {, } \\
\beta \text {-tubulin }][15,97]\end{array}$ & - \\
\hline & & & & Ozone [hsp 70] [97] & NA \\
\hline & & & & Ammonia [hsp ro] [144] & NA \\
\hline & & & & Heat $60^{\circ} \mathrm{C}$ to $95^{\circ} \mathrm{C}[h s p 70][97,209]$ & - \\
\hline & & & & Freeze $[h s p 70][97]$ & NA \\
\hline & & & & Storage $15^{\circ} \mathrm{C}(9 \mathrm{~m})[c p a g][114,115]$ & $+/-$ \\
\hline & & & & Storage $4^{\circ} \mathrm{C}(48 \mathrm{~m})[h s p 70][144]$ & NA \\
\hline & & & & $\begin{array}{l}\text { Storage RT and } 4{ }^{\circ} \mathrm{C}(20 \text { to } 39 \mathrm{w}) \\
{[\beta \text {-tubulin }][226]} \\
\text { Food matrix: } \\
\text { Storage } 4{ }^{\circ} \mathrm{C}(8 \mathrm{~d})-\text { Basil }[h s p 70][104]\end{array}$ & NA \\
\hline & \multirow[t]{3}{*}{$\mathrm{G}$} & \multirow[t]{3}{*}{ Wastewater $[17,24]$} & \multirow[t]{3}{*}{ NA } & $\begin{array}{l}\text { Simple matrix: } \\
\text { Heat } 60^{\circ} \mathrm{C} \text { to } 95^{\circ} \mathrm{C}[\beta \text {-giardin }][209]\end{array}$ & - \\
\hline & & & & Food matrix: & \\
\hline & & & & Storage $4{ }^{\circ} \mathrm{C}(8 \mathrm{~d})-$ Basil [ $\beta$-giardin] [104] & NA \\
\hline
\end{tabular}


Table 2. (continued).

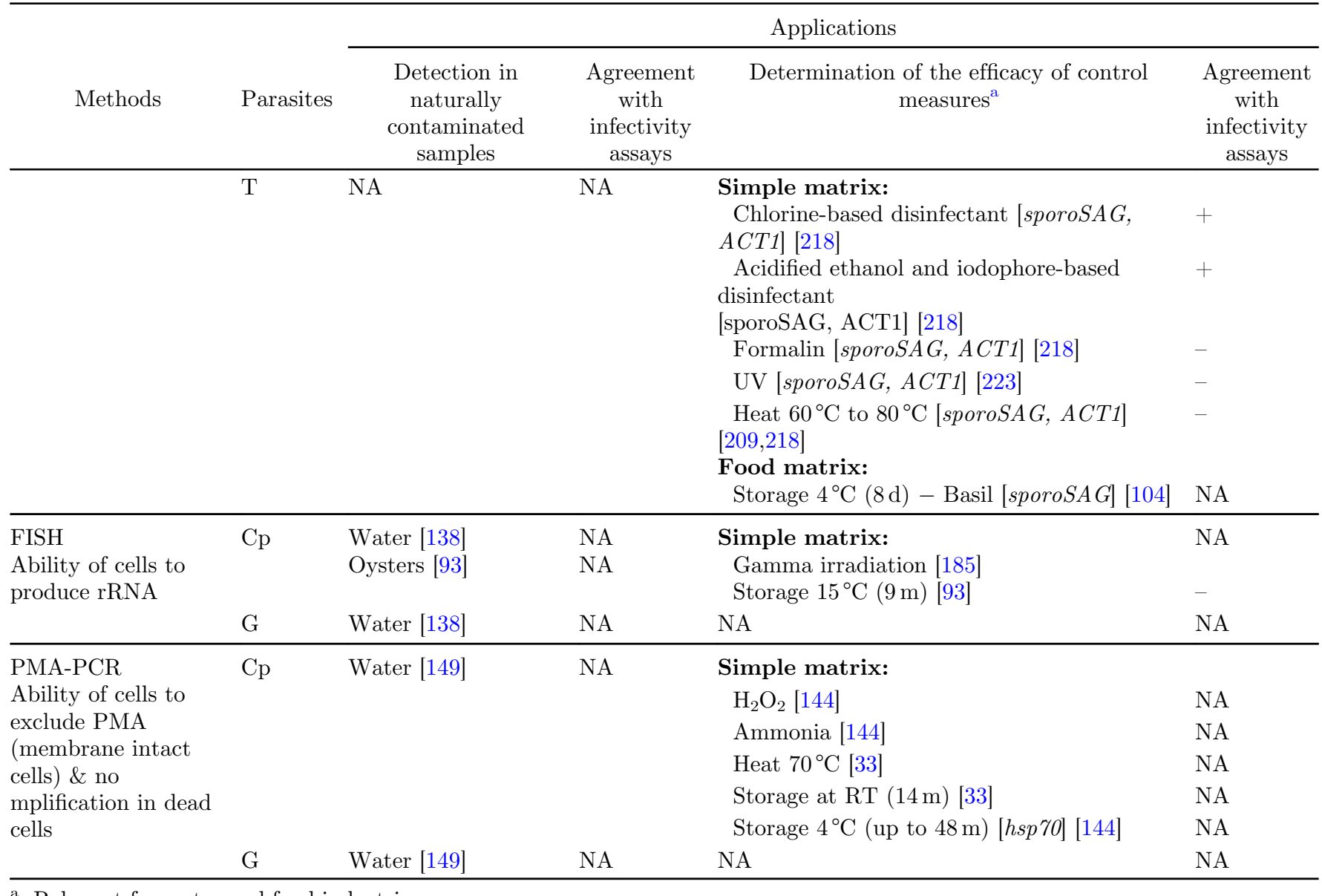

a Relevant for water and food industries;

b Simple matrix: water or buffer.

NA: No available data. Cp: C. parvum; G: Giardia duodenalis; T:Toxoplasma gondii.

$\mathrm{H}_{2} \mathrm{O}_{2}$ : hydrogen peroxide; UV: ultraviolet; RT: room temperature; m: months; w: weeks; d: days.

$(-)$ : no agreement with infectivity assays means that: i) viability and infectivity assays are not concordant (i.e. viability $(+)$ and infectivity (-), and conversely (rarely)); ii) and/or lower inactivation levels or no inactivation are measured by viability assays compared to infectivity assays.

$(+)$ : viability and infectivity assays are concordant.

$(+/-)$ : agreement with infectivity varies according to studies

$\S: 12 / 15$ samples showed no correlation with cell culture assays.

\subsubsection{Dye inclusion/exclusion methods}

In order to overcome some of the deficiencies of the dye exclusion technique, inclusion-exclusion methods have been developed in which viable cells, as well as excluding specific dyes, also include specific dyes, and the dyes are used simultaneously in an inclusion-exclusion assay. One approach is to incubate cells with a non-fluorescent dye. These diffuse into living cells and then, following cleavage by intracellular enzymes present only in live cells, a fluorescent molecule is produced which is then detected. One such dye is fluorescein diacetate (FDA), which is nontoxic for many cell types [189], and is a substrate for a cell-permanent esterase leading to the production of fluorescein, which accumulates in live cells only if their membrane is intact, and exhibits green fluorescence when excited by blue light, indicating a viable cell. This was suggested to be used in conjunction with PI as an exclusioninclusion assay for Giardia muris cysts, as a model for $G$. duodenalis [192]. Unfortunately, however, further investigation revealed that $G$. duodenalis cysts that stained with PI could also often stain with FDA [199], presumably because of the enzyme remaining active despite the cyst itself no longer being viable. A similar approach has also been followed with the redox dye 5-cyano-2,3-ditolyl tetrazolium chloride (CTC), that should only show staining when the respiratory electron transport system (ETS) shows activity (i.e., the parasite is viable). Although initial studies provided promising results [113], the same type of problem of activity even in dead cells is likely to limit the usefulness of this approach. An alternative approach to these non-fluorescent dyes is the use of dyes that are nuclear intercalates such as SYTO-9, SYTO-17, SYTO-59-64 and hexidium, and DAPI. SYTO-dyes seem 
Table 3. Advantages and limitations of the techniques used to assess infectivity and viability.

\begin{tabular}{|c|c|c|c|}
\hline Methods & Parasites & Advantages & Limitations \\
\hline $\begin{array}{c}\text { Bioassays } \\
{[\mathrm{I}]}\end{array}$ & $\mathrm{Cp} \& \mathrm{Ch} / \mathrm{G} / \mathrm{T}$ & $\begin{array}{l}\text { - Requires a single (oo)cyst } \\
\text { - Application on complex food matrices } \\
\text { - Reliable exposure assessment of humans } \\
\text { to infective protozoa. } \\
\text { - Reliable assessment of inactivation } \\
\text { efficacy }\end{array}$ & $\begin{array}{l}\text { - Ethical concerns } \\
\text { - Expensive method and labor intensive } \\
\text { - Lack of reliability with low numbers of (oo)cysts } \\
\text { - Discrimination of large but not fine differences } \\
\text { between treatments } \\
\text { - Long time-to-results (one week minimum) }\end{array}$ \\
\hline $\begin{array}{l}\text { Cell Culture } \\
{[\mathrm{I}]}\end{array}$ & $\mathrm{Cp} \& \mathrm{Ch} / \mathrm{T}$ & $\begin{array}{l}\text { - Correlation with bioassays } \\
\text { - Requires a single (oo)cyst } \\
\text { - Reliable exposure assessment of humans } \\
\text { to infective protozoa } \\
\text { - Reliable assessment of inactivation } \\
\text { efficacy }\end{array}$ & $\begin{array}{l}\text { - Lack of standardized assays } \\
\text { - Medium (48/72h) to long (10 days) time to } \\
\text { results } \\
\text { - Not applicable to Giardia } \\
\text { - No application on complex food matrices }\end{array}$ \\
\hline $\begin{array}{l}\text { Methods based on } \\
\text { morphology and } \\
\text { physical properties } \\
{[\mathrm{V}]}\end{array}$ & $\mathrm{C} / \mathrm{G}$ & $\begin{array}{l}\text { - Correlation between electrorotation and } \\
\text { PI exclusion method } \\
\text { - Rapid } \\
\text { - Require a single (oo)cyst }\end{array}$ & $\begin{array}{l}\text { - Require purified (oo)cysts } \\
\text { - No data on viability relative to infectivity } \\
\text { measure } \\
\text { - No application in exposure assessment in food }\end{array}$ \\
\hline $\begin{array}{l}\text { Excystation } \\
{[\mathrm{V}]}\end{array}$ & $\mathrm{C} / \mathrm{G} / \mathrm{T}$ & $\begin{array}{l}\text { - Correlation with PI exclusion method } \\
\text { - Rapid } \\
\text { - Non-expensive }\end{array}$ & $\begin{array}{l}\text { - Requires large numbers of purified (oo)cysts } \\
\text { - Variable excystation rate } \\
\text { - Over/underestimation of the exposure of } \\
\text { humans to infective protozoa } \\
\text { - Over/underestimation of inactivation efficacy } \\
\text { - No application on complex food matrices }\end{array}$ \\
\hline $\begin{array}{l}\text { Vital dye exclusion } \\
{[\text { [V] }}\end{array}$ & $\mathrm{C} / \mathrm{G} / \mathrm{T}$ & $\begin{array}{l}\text { - Correlation with excystation for PI } \\
\text { dye }(\mathrm{C}) \\
\text { - Rapid and relatively simple } \\
\text { - Non-expensive } \\
\text { - Requires a single (oo)cysts } \\
\text { - Application on complex food matrices }\end{array}$ & $\begin{array}{l}\text { - Requires purified (oo)cysts } \\
\text { - Few applications for T. gondii } \\
\text { - Overestimation of the exposure of humans to } \\
\text { infective protozoa } \\
\text { - Underestimation of inactivation efficacy }\end{array}$ \\
\hline $\begin{array}{c}\text { RT-PCR } \\
{[\text { V] }}\end{array}$ & $\mathrm{C} / \mathrm{G} / \mathrm{T}$ & $\begin{array}{l}\text { - Rapid } \\
\text { - Identification of (oo)cysts of human } \\
\text { health significance } \\
\text { - Easy to standardize } \\
\text { - Requires low numbers of (oo)cysts } \\
\text { - Application on complex food matrices }\end{array}$ & $\begin{array}{l}\text { - Limit of detection variable depending on } \\
\text { matrices } \\
\text { - Overestimation of the exposure of humans to } \\
\text { infective protozoa } \\
\text { - Underestimation of inactivation efficacy }{ }^{*}\end{array}$ \\
\hline $\begin{array}{c}\text { FISH } \\
{[\mathrm{V}]}\end{array}$ & $\mathrm{C}$ & $\begin{array}{l}\text { - Rapid } \\
\text { - Non-expensive } \\
\text { - Requires a single (oo)cysts }\end{array}$ & $\begin{array}{l}\text { - Requires purified (oo)cysts } \\
\text { - Overestimation of the exposure of humans to } \\
\text { infective protozoa } \\
\text { - Underestimation of inactivation efficacy }{ }^{*} \\
\text { - No application on complex food matrices }\end{array}$ \\
\hline $\begin{array}{c}\text { NASBA } \\
{[\mathrm{V}]}\end{array}$ & $\mathrm{C}$ & $\begin{array}{l}\text { - Correlation with PI exclusion method } \\
\text { - Rapid } \\
\text { - Non-expensive } \\
\text { - Requires low numbers of (oo)cysts }\end{array}$ & $\begin{array}{l}\text { - Overestimation of the viable population } \\
\text { - Non-quantitative } \\
\text { - No data on viability relative to infectivity } \\
\text { measure } \\
\text { - No application in exposure assessment in food }\end{array}$ \\
\hline $\begin{array}{l}\text { PMA-PCR } \\
{[\mathrm{V}]}\end{array}$ & $\mathrm{C}$ & $\begin{array}{l}\text { - Rapid } \\
\text { - Requires low numbers of (oo)cysts } \\
\text { - Can be coupled to genotyping } \\
\text { - Easy to standardize }\end{array}$ & $\begin{array}{l}\text { - Overestimation of the viable population } \\
\text { - No data on viability relative to infectivity } \\
\text { measure } \\
\text { - No application in exposure assessment in food }\end{array}$ \\
\hline
\end{tabular}

[I]: infectivity. [V]: viability. C: Cryptosporidium spp.; Cp: C. parvum; Ch: C. hominis; G: Giardia duodenalis; T: Toxoplasma gondii. Based on the comparison of viability relative to infectivity.

to provide viability assay results that correlate with the infectivity of C. parvum oocysts to CD-1 mice but not to excystation assays $[19,20,165]$ assessing the efficacy of oxidants, UV and thermal treatments. That said, recent experiments have shown that of seven SYTO dyes investigated, all were more likely to stain dead Cryptosporidium oocysts than live oocysts [208], indicating some degree of confusion around use of vital dye stains.
In conclusion, there is considerable confusion and potential for subjectivity regarding dyes used for inclusion. Vital dye exclusion overestimates the exposure of humans to infective protozoa, suggesting that this technique may not be appropriate for exposure assessment. However, given its applicability to foods, its suitability for low numbers of parasites, and its costeffectiveness, among others advantages (Table 3), it may 
provide initial results, particularly when investigating whether individual parasites identified on fresh produce are potentially infectious or whether a treatment is efficient to kill (oo)cysts.

\subsection{Molecular methods}

\subsubsection{RNA-based methods}

\subsubsection{Reverse Transcriptase-PCR (RT-PCR)}

RT-PCR techniques are emerging as alternatives to the use of vital dyes for evaluating viability. These methods are based on the production of mRNA in cells that are metabolically functional and active, and hence considered as viable.

\subsection{Cryptosporidium parvum}

For Cryptosporidium oocysts, RT-PCR assays targeting the $h s p 70$ gene have been described as being highly sensitive. Indeed, the level of $h s p 70$ mRNA can be enhanced by heating. This allows increasing the sensitivity especially when working on initial low levels of mRNA or in complex matrices [81]. Other targets have also been described, such as genes encoding $\beta$-tubulin [226], amylogluconidase [114], COWP, CP2 or $18 \mathrm{~S}$ rDNA [135]. However, 18S rRNA remains stable for a prolonged period (up to at least $48 \mathrm{~h}$ ) in heat-killed oocysts, and hence is not a good marker of viability $[76,135]$. RT-PCR was used to assess the efficacy of temperature and chemicals on Cryptosporidium oocysts in simple and complex matrices (Table 2). However, correlation with infectivity seems to depend on the applied treatments and the targeted mRNA: $\beta$-tubulin mRNA production was reported to correlate with oocyst infectivity after longterm storage at cold and room temperatures but not following oxidant treatments, while $h s p 70 \mathrm{mRNA}$ production correlated with cell culture assays in oocysts submitted to oxidants, but not to heat treatment (Table 2).

\subsection{Giardia duodenalis}

The hsp 70 gene has also been described for the detection of viable Giardia cysts in simplex assays $[1,134]$, but also in duplex RT-PCR with $C$. parvum [163]. Other targets such as ef1a, adhe and $\beta$-giardin mRNAs have been used, the latter being the most suitable to study the viability of Giardia cysts in environmental samples (Table 2). However, $\beta$-giardin mRNA RT-PCR assays have been shown to detect viable but non-infectious cysts following heat treatments, indicating that this method underestimates the efficacy of these treatments (Tables 2 and 3).

\subsection{Toxoplasma gondii}

To estimate the viability of $T$. gondii oocysts, RTPCR assays targeting two genes have been described:
SporoSAG, which is highly expressed in the sporulated oocyst, and act1 expressed in both sporulated and unsporulated oocysts [218]. As previously described for Cryptosporidium, correlation of RT-PCR with infectivity assays appears variable according to the applied treatments, with good agreement following chlorine- and iodine-based disinfectants, and acidified-ethanol, but not after heating or exposure to formalin or UV (Table 2).

To summarize, the RT-qPCR technique is rapid, sensitive, and can directly assess the likelihood for a human to be infected by detected protozoa. However, although mRNA is the least stable nucleic acid, compared with rDNA, tRNA and rRNA, it can nevertheless persist for a long time after the death of the parasites, even in nonfavorable conditions. This has recently been described for mRNA from dead Plasmodium ookinetes that remained detectable more than $24 \mathrm{~h}$ inside the mosquito midgut [96]. Hence, RT-qPCR assays can overestimate the number of viable and potentially infectious (oo)cysts, and consequently will overestimate the exposure of humans to infective parasites and underestimate the efficacy of control measures (Table 3). However, this method can be useful as a first step of screening of different treatments applied to complex matrices to benchmark inactivation potential.

\subsubsection{Fluorescence in situ hybridization (FISH)}

The fluorescence in situ hybridization (FISH) method consists in targeting a nucleic acid sequence using a specific synthetic fluorescent oligonucleotide probe. rRNA is considered to be the ideal viability target for several reasons: (i) high sensitivity; (ii) short half-life (although as described in 3.4.1.1, in parasites the half-life is longer); (iii) present in high copy number in viable cells [9]. Hence, a FISH 'positive' signal depends on the amount of target rRNAs present in a cell, the longevity of that target within the cell and accessibility for probing, the fluorescence intensity of bound probe and the presence of RNases. Probes targeting different regions of the $18 \mathrm{~S}$ rRNA specific to $C$. parvum, C. hominis and $G$. duodenalis have been described for the detection of viable (oo)cyst [5,48,92,217]. The FISH technique is described as a rapid and cheap method, with a fast time-to-result (3 hours), enabling the specific simultaneous visualization of one or more viable (oo)cyst species [92,138]. Nevertheless, it remains scarcely used in surveys (Table 2). Although in some studies FISH assays have shown correlation with in vitro excystation of C. parvum oocysts [217], this is not always the case and no agreement with infectivity assays has been observed [115]. Furthermore, rRNA is able to persist for 6 days after $C$. parvum oocyst heat treatment, presumably because it is protected within the oocyst [200], and consistent with this, gamma-irradiated oocysts of Cryptosporidium have been shown to give a positive FISH signal while being dead (Table 2). Thus, this method cannot be considered as a reliable measure to assess the exposure of humans to infective (oo)cysts and the inactivation efficacy of treatments (Table 3). 


\subsubsection{Nucleic Acid Sequence-Based Amplification (NASBA)}

Nucleic acid sequence-based amplification (NASBA) is an isothermal and sensitive technique for amplification of RNA targets that has been described for many microorganisms and has recently been reviewed [106]. This method can detect viable cells through selective amplification of mRNA, even in a background of genomic DNA. Compared with RT-qPCR techniques, amplification is performed at a single temperature $\left(41^{\circ} \mathrm{C}\right)$, and consequently does not need thermal cycling equipment. The detection of products of NASBA reaction is quite laborintensive including ethidium bromide-stained agarose gel electrophoresis, which requires a confirmatory step by probe hybridization, enzyme-linked gel assays, electrochemiluminescence (ECL) detection and fluorescence correlation spectroscopy. MIC1 and hsp $70 \mathrm{mRNAs}$ have been described as target molecules for Cryptosporidium oocysts $[13,107]$. This method has been shown to correlate with the PI exclusion method [44] and to be suitable to detect viable $C$. parvum oocysts in spiked environmental waters, in the presence of organic, inorganic and biological contaminants, and with detection limit below ten viable oocysts per analyzed sample [13]. However, oocysts that had been killed by exposure to sodium hypochlorite, freeze-thawing or boiling were also detected, indicating again the stability of the RNA and the lack of suitability of this method for detecting only viable oocysts; indeed, freeze-thawing seemed to give an even stronger NASBA signal [107]. To date, no study describes the use of this method to evaluate the occurrence of parasites in naturally contaminated samples and to assess the efficacy of industrial processes on the protozoan parasites, and no such assays have been proposed for $T$. gondii or $G$. duodenalis.

In conclusion, because of the stability of mRNA for extended periods in oocysts that have been experimentally inactivated (e.g., after heating, freeze-thawing or chemical treatments), it is clear that this technique detects both live and dead oocysts. Moreover, although quantitative NASBA has been described, the cell concentration seems not to be reliable, and thus this method is unsuitable for inactivation studies. Therefore, this technique appears not to be appropriate for exposure assessment in food (Table 3).

\subsubsection{DNA-based methods: EMA/PMA PCR}

Combination of viability dyes like EMA and PMA with PCR has been developed to study the viability of different foodborne pathogens [231]. As described in the "dyes" section (3.3.1), the use of EMA and PMA in viability assessment is based on the impermeability of live cells to both dyes that penetrate damaged and permeable cell (considered as non-viable) only. Once inside the nucleus, EMA and PMA can be photoactivated, which leads to their covalent binding to DNA and prevents PCR amplification in non-viable cells $[30,75]$. Thus, a PCR signal should be obtained only for viable cells (i.e. nondamaged and non-permeable cells). However, in contrast with PMA, EMA has been described as able to penetrate into viable cells due to the variability of cell membrane structure and of active membrane transport efficacy [75,168]. EMA is also considered more toxic than PMA and this toxicity is time and temperature dependent [75]. Hence, PMA should lead to better discrimination of viable cells than EMA.

PMA-PCR and PMA-qPCR targeting the hsp \%0, COWP and 18S rRNA encoding genes have been described for Cryptosporidium oocysts [3,7,33,144]. For Giardia, PMA-qPCR based on the detection of the b-giardin gene has been shown to be able to quantify viable cysts in artificially contaminated wastewater samples accurately. This target has appeared as more effective than the triosephosphate isomerase $(t p i)$ and glutamate dehydrogenase $(G D H)$ genes [7]. In this study, the authors have also shown that the longer the amplicon, the more effective the exclusion of dead cysts. Comparison with infectivity assays has not been performed, and PMA-qPCR appears not to correlate with RT-qPCR data (unpublished data). Only a few studies have described the use of PMA-PCR to identify viable parasites in naturally contaminated water samples, and to assess the efficacy of chemicals and temperature on Cryptosporidium oocysts and Giardia cysts (Table 2). Up to now, no study has described PMAqPCR applied to T. gondii. However, the ability to specifically detect viable protozoa seems to depend on the applied treatment and is impaired in complex samples (unpublished data). Thus, this technique may overestimate the exposure to infective protozoa.

\section{Conclusion}

To date, only techniques allowing infectivity evaluation are able to provide a reliable assessment of the exposure of humans to protozoa in food (Table 3 ). They can even be sufficiently sensitive to detect low levels of contamination and directly address the likelihood that individuals will be infected by consumption of contaminated food. On the one hand, bioassays can be directly applied to food samples but they suffer from major ethical concerns; additionally they are restrictive, expensive, and implementation is complex, with prolonged time-toresults. Hence, bioassays are not suitable for routine analysis for control measure verifications or any surveys intended to assess the global exposure of consumers. On the other hand, cell cultures can produce results more rapidly (but still 2 to 10 days), and this method could be more available and appropriate for routine laboratories (but still requiring specific skills, including long-term cell culture). However, it requires purified (oo)cysts, which can be challenging to obtain when working on food matrices. Both methods produce reliable inactivation data, but some authors have suggested that bioassays and cell culture may be able to highlight only substantial inactivation. 
Most techniques assessing (oo)cyst viability appear to overestimate the occurrence of infective parasites and subsequent exposure of humans along the food chain. When used for investigating the efficacy of control measures, they tend to underestimate their inactivation efficacy (Table 3). RNA-amplification based assays (RTPCR, NASBA) are interesting alternative techniques because they can be standardized and may be suitable for routine analyses of food samples (implementation and results interpretation). Moreover, being a quantitative approach, RT-qPCR allows the definition of viability reduction levels. However, these positive aspects are undermined by the apparent and clear stability of RNA within parasites, such that dead parasites are likely to be considered viable, overestimating exposure of humans to infective parasites and underestimating the efficacy of control measures. Although PMA-PCR seems to be an exciting and relevant technique, unfortunately it is only limited to simple matrices and to the evaluation of control measures that would permeabilize the (oo)cysts and allow the dye to penetrate. Excystation assays provide an active measure of activity and the effect of an intervention, but require clean suspensions and high numbers of parasites to be of any use. Their application beyond experimental studies of Cryptosporidium oocysts seems limited, and they are not easy to standardize in routine laboratory analyses. Although vital dye assays have considerable limitations, particularly with respect to overestimation of viability due to membrane impermeability not necessarily correlating with viability, and the subjectivity of any microscopy-based technique, their simplicity, cost-effectiveness, and potential for application to low parasite numbers may make them useful for initial screening purposes - both with regard to assessing infection potential of contaminant parasites and investigating treatment effects. However, results should always be backed up with another technique, and their disadvantages should not be overlooked.

To conclude, none of the techniques currently available appear to be entirely suitable for reliable assessment of the exposure of humans to infective protozoa in food or for routine verifications of control measures. In order to be able to produce data to refine exposure and subsequently better characterize the risk, we suggest that two actions should be carried out in parallel: - i) Determine initial levels of contamination using DNAbased assays: these are known to be sensitive enough for detecting low quantities of parasites, are easy to standardize, and are accessible for routine analyses. Although false positives are not expected, their potential should not be overlooked due to the occurrence of "loose" target DNA, without the actual organism being present. These methods overestimate the exposure to infective parasites by detecting all populations of (oo)cysts (i.e. live and infectious, live and non-infectious, dead), and therefore will give the maximum occurrence and level of contamination for a given matrix. For Cryptosporidium and Giardia, determination of the species and the genetic assemblages respectively, is part of the exposure assessment. These important taxonomic details can be determined by DNA-based assays and directly address the infectious potential for humans.

- ii) Characterize the efficacy of treatments in place to control parasites using a combination of techniques. Simple vital dye inclusion/exclusion methods may be the preliminary approach, providing initial data on the inactivation potential of different treatments. To determine inactivation levels, which are the reference measure for food operators ( $\log _{10}$ viability reduction), RT-qPCR-based assays could be applied. They will overestimate the level of infective protozoa (quantification of live and infectious, live and non-infectious, and possibly dead (oo)cysts), leading to an underestimation of the efficacy of the treatments. But this action will allow the determination of the "worst case scenario" for a specific combination food/process, providing at the same time, confidence that when a target inactivation is reached, higher inactivation occurs in reality. Cell culture methods are improving in applicability, and, as imaging techniques become more accessible and cheap, will be of value in assessing invasion of cell cultures. Appropriate infectivity assays (bioassays), should be minimized for ethical and operational reasons, but can be used to confirm results obtained by in vitro assays.

All viability assays are based on evaluation of distinct physiological parameters that could vary depending on the applied treatments, the protozoa in question, and their original physiological state. Hence, future research should focus on the characterization of the effect of inactivation methods on the structure and the metabolism of (oo)cysts to be able to select and develop suitable techniques for infectivity measurement.

Acknowledgements. This work was funded by the UMT ACTIA PROTORISK and the University of Reims ChampagneArdenne, in the framework of a $\mathrm{PhD}$ thesis with a CIFRE agreement between ACTALIA and the French Ministry of Higher Education, Research and Innovation. This work was also supported by the French National Research Agency (grant ANR-17-CE21-0005-07). This review is based upon collaboration within the framework of Working Group 3 of COST Action FA1408 "A European Network for Foodborne Parasites: EuroFBP", supported by COST (European Cooperation in Science and Technology).

\section{Conflict of interest}

The authors declare no conflict of interest.

\section{References}

1. Abbaszadegan M, Huber MS, Gerba CP, Pepper IL. 1997. Detection of viable Giardia cysts by amplification of heat shock-induced mRNA. Applied and Environmental Microbiology, 63, 324-328.

2. Adell AD, Miller WA, Harvey DJ, Van Wormer E, Wuertz S, Conrad PA. 2014. Individual subject meta-analysis of parameters for Giardia duodenalis shedding in animal experimental models. BioMed Research International, 2014, 476142 . 
3. Agulló-Barceló M, Moss JA, Green J, Gillespie S, Codony F, Lucena F, Nocker A. 2014. Quantification of relative proportions of intact cells in microbiological samples using the example of Cryptosporidium parvum oocysts. Letters in Applied Microbiology, 58, 70-78.

4. Aksoy U, Marangi M, Papini R, Ozkoc S, Bayram Delibas S, Giangaspero A. 2014. Detection of Toxoplasma gondii and Cyclospora cayetanensis in Mytilus galloprovincialis from Izmir Province coast (Turkey) by Real Time PCR/ High-Resolution Melting analysis (HRM). Food Microbiology, 44, 128-135.

5. Alagappan A, Bergquist PL, Ferrari BC. 2009. Development of a two-color fluorescence in situ hybridization technique for species-level identification of human-infectious Cryptosporidium spp. Applied and Environmental Microbiology, 75, 5996-5998.

6. Alarcón MA, Beltrán M, Cárdenas ML, Campos MC. 2005. Presence and viability of Giardia spp. and Cryptosporidium spp. in drinking water and wastewater in the high basin of Bogotá river. Biomedica, 25, 353-365.

7. Alonso JL, Amorós I, Guy RA. 2014. Quantification of viable Giardia cysts and Cryptosporidium oocysts in wastewater using propidium monoazide quantitative realtime PCR. Parasitology Research, 113, 2671-2678.

8. Alum A, Sbai B, Asaad H, Rubino JR, Khalid Ijaz M. 2012. ECC-RT-PCR: a new method to determine the viability and infectivity of Giardia cysts. International Journal of Infectious Diseases, 16, e350-e353.

9. Amann RI, Ludwig W, Schleifer K-H. 1995. Phylogenetic identification and in situ detection of individual microbial cells without cultivation. Microbiological Reviews, 59, $143-169$.

10. Amorós I, Alonso JL, Cuesta G. 2010. Cryptosporidium oocysts and Giardia cysts on salad products irrigated with contaminated water. Journal of Food Protection, 73, $1138-1140$.

11. Arrowood MJ, Xie L-T, Rieger K, Dunn J. 1996. Disinfection of Cryptosporidium parvum oocysts by pulsed light treatment evaluated in an in vitro cultivation model, 1996. Journal of Eukaryotic Microbiology, 43, 88S-88S.

12. Aubert D, Villena I. 2009. Detection of Toxoplasma gondii oocysts in water: proposition of a strategy and evaluation in Champagne-Ardenne Region, France. Memórias do Instituto Oswaldo Cruz, 104, 290-295.

13. Baeumner AJ, Humiston MC, Montagna RA, Durst RA. 2001. Detection of viable oocysts of Cryptosporidium parvum following nucleic acid sequence based amplification. Analytical Chemistry, 73, 1176-1180.

14. Baishanbo A, Gargala G, Delaunay A, François A, Ballet J-J., Favennec L. 2005. Infectivity of Cryptosporidium hominis and Cryptosporidium parvum genotype 2 isolates in immunosuppressed mongolian gerbils. Infection and Immunity, 73, 5252-5255.

15. Bajszár G, Dekonenko A. 2010. Stress-induced hsp 70 gene expression and inactivation of Cryptosporidium parvum oocysts by chlorine-based oxidants. Applied and Environmental Microbiology, 76, 1732-1739.

16. Baldursson S, Karanis P. 2011. Waterborne transmission of protozoan parasites: Review of worldwide outbreaks An update 2004-2010. Water Research, 45, 6603-6614.

17. Baque RH, Gilliam AO, Robles RD, Jakubowski W, Slifko TR. 2011. A real-time RT-PCR method to detect viable Giardia lamblia cysts in environmental waters. Water Research, 45, 3175-3184.

18. Belosevic M, Faubert GM, MacLean JD, Law C, Croll NA. 1983. Giardia lamblia infections in Mongolian gerbils: an animal model. Journal of Infectious Diseases, 147, 222-226.
19. Belosevic M, Guy RA, Taghi-Kilani R, Neumann NF, Gyürék LL, Liyanage LRJ, Millard PJ, Finch GR. 1997. Nucleic acid stains as indicators of Cryptosporidium parvum oocyst viability. International Journal for Parasitology, 27, 787-798.

20. Belosevic M, Guy RA, Taghi-Kilani R, Neumann NF. 1997. Vital dye staining of Giardia and Cryptosporidium. American Water Works Association, Denver, Co.

21. Benamrouz S, Guyot K, Gazzola S, Mouray A, Chassat T, Delaire B, Chabé M, Gosset P, Viscogliosi E, Dei-Cas E, Creusy C, Conseil V, Certad G. 2012. Cryptosporidium parvum infection in SCID mice infected with only one oocyst: qPCR assessment of parasite replication in tissues and development of digestive cancer.PLOS ONE, 7, e51232.

22. Benedict KM, Reses H, Vigar M, Roth DM, Roberts VA, Mattioli M, Cooley LA, Hilborn ED, Wade TJ, Fullerton KE, Yoder JS, Hill VR. 2017. Surveillance for waterborne disease outbreaks associated with drinking water United States, 2013-2014. Morbidity and Mortality Weekly Report, 66, 1216-1221.

23. Bénéré E, Van Assche T, Van Ginneken C, Peulen O, Cos P, Maes L. 2012. Intestinal growth and pathology of Giardia duodenalis assemblage subtype A(I), A(II), B and $\mathrm{E}$ in the gerbil model. Parasitology, 139, 424-433.

24. Bertrand I, Maux M, Helmi K, Hoffmann L, Schwartzbrod J, Cauchie H-M. 2009. Quantification of Giardia transcripts during in vitro excystation: interest for the estimation of cyst viability. Water Research, 43, 27282738 .

25. Bingham AK, Jarroll EL Jr, Meyer EA, Radulescu S. 1979. Giardia sp.: physical factors of excystation in vitro, and excystation vs eosin exclusion as determinants of viability. Experimental Parasitology, 47: 284-91.

26. Bingham AK, Meyer EA. 1979. Giardia excystation can be induced in vitro in acidic solutions. Nature, 277, 301302.

27. Biswas K, Craik S, Smith DW, Belosevic M. 2003. Synergistic inactivation of Cryptosporidium parvum using ozone followed by free chlorine in natural water. Water Research, 37, 4737-4747.

28. Biswas K, Craik S, Smith DW, Belosevic M. 2005. Synergistic inactivation of Cryptosporidium parvum using ozone followed by monochloramine in two natural waters. Water Research, 39, 3167-3176.

29. Black EK, Finch GR, Taghi-Kilani R, Belosevic M. 1996. Comparison of assays for Cryptosporidium parvum oocysts viability after chemical disinfection. FEMS Microbiology Letters, 135, 187-189.

30. Bolton PH, Kearns DR. 1978. Spectroscopic properties of ethidium monoazide: a fluorescent photoaffinity label for nucleic acids. Nucleic Acids Research, 5, 4891-4903.

31. Boyer K, Hill D, Mui E, Wroblewski K, Karrison T, Dubey JP, Sautter M, Noble AG, Withers S, Swisher C, Heydemann P, Hosten T, Babiarz J, Lee D, Meier P, McLeod R, Toxoplasmosis Study Group. 2011. Unrecognized ingestion of Toxoplasma gondii oocysts leads to congenital toxoplasmosis and causes epidemics in North America. Clinical Infectious Diseases, 53, 1081-1089.

32. Brasseur P, Lemeteil D, Ballet JJ. 1988. Rat model for human cryptosporidiosis. Journal of Clinical Microbiology, 26, 1037-1039.

33. Brescia CC, Griffin SM, Ware MW, Varughese EA, Egorov AI, Villegas EN. 2009. Cryptosporidium propidium monoazide-PCR, a molecular biology-based technique for genotyping of viable Cryptosporidium oocysts. Applied and Environmental Microbiology, 75, 6856-6863. 
34. Bukhari Z, Marshall MM, Korich DG, Fricker CR, Smith HV, Rosen J, Clancy JL. 2000. Comparison of Cryptosporidium parvum viability and infectivity assays following ozone treatment of oocysts. Applied and Environmental Microbiology, 66, 2972-2980.

35. Buraud M, Forget E, Favennec L, Bizet J, Gobert JG, Deluol AM. 1991. Sexual stage development of cryptosporidia in the Caco-2 cell line. Infection and Immunity, 59, 4610-4613.

36. Campbell AT, Robertson LJ, Smith HV. 1992. Viability of Cryptosporidium parvum oocysts: correlation of in vitro excystation with inclusion or exclusion of fluorogenic vital dyes. Applied and Environmental Microbiology, 58, 34883493.

37. Campbell AT, Wallis P. 2002. The effect of UV irradiation on human-derived Giardia lamblia cysts. Water Research, 36, 963-969.

38. Certad G, Ngouanesavanh T, Guyot K, Gantois N, Chassat T, Mouray A, Fleurisse L, Pinon A, Cailliez JC, Dei-Cas E, Creusy C. 2007. Cryptosporidium parvum, a potential cause of colic adenocarcinoma. Infectious Agents and Cancer, 2007, 2-22

39. Chaidez C, Soto M, Gortares P, Mena K. 2005. Occurrence of Cryptosporidium and Giardia in irrigation water and its impact on the fresh produce industry. International Journal of Environmental Health Research, 15, 339-345.

40. Chappell CL, Okhuysen PC, Langer-Curry R, Widmer G, Akiyoshi DE, Tanriverdi S, Tzipori S. 2006. Cryptosporidium hominis: experimental challenge of healthy adults. American Journal of Tropical Medicine and Hygiene, 75, 851-857.

41. Chochillon C, Favennec L, Gobert JG, Savel J. 1990. Giardia intestinalis: étude des modalités de l'infestation du souriceau avant le sevrage. Comptes Rendus des Séances de la Société de Biologie et de ses Filiales, 184, 150-157.

42. Collins MV, Flick GJ, Smith SA, Fayer R, Croonenberghs R, O'Keefe S, Lindsay DS. 2005. The effect of highpressure processing on infectivity of Cryptosporidium parvum oocysts recovered from experimentally exposed eastern oysters (Crassostrea virginica). Journal of Eukaryotic Microbiology, 52, 500-504.

43. Collins MV, Flick GJ, Smith SA, Fayer R, Rubendall E, Lindsay DS. 2005. The effects of e-beam irradiation and microwave energy on eastern oysters (Crassostrea virginica) experimentally infected with Cryptosporidium parvum. Journal of Eukaryotic Microbiology, 52, 484-488.

44. Connelly JT, Nugen SR, Borejsza-Wysocki W, Durst RA, Montagna RA, Baeumner AJ. 2008. Human pathogenic Cryptosporidium species bioanalytical detection method with single oocyst detection capability. Analytical and Bioanalytical Chemistry, 391, 487-495.

45. Costa AO, Thomaz-Soccol V, Clara Paulino R, Alcântara de Castro E. 2009. Effect of vinegar on the viability of Giardia duodenalis cysts. International Journal of Food Microbiology, 128, 510-512.

46. Craik SA, Weldon D, Finch GR, Bolton JR, Belosevic M. 2001. Inactivation of Cryptosporidium parvum oocysts using medium- and low-pressure ultraviolet radiation. Water Research, 35, 1387-1398.

47. Dalton C, Goater AD, Pethig R, Smith HV. 2001. Viability of Giardia intestinalis cysts and viability and sporulation state of Cyclospora cayetanensis oocysts determined by electrorotation. Applied and Environmental Microbiology, 67, 586-590.

48. Deere D, Vesey G, Ashbolt N, Davies KA, Williams KL, Veal D. 1998. Evaluation of fluorochromes for flow cytometric detection of Cryptosporidium parvum oocysts labelled by fluorescent in situ hybridization. Letters in Applied Microbiology, 27, 352-356.

49. Delaunay A, Gargala G, Li X. Favennec L, Ballet JJ. 2000. Quantitative flow cytometric evaluation of maximal Cryptosporidium parvum oocyst infectivity in a neonate mouse model. Applied and Environmental Microbiology, $66,4315-4317$.

50. DeSilva MB, Schafer S, Kendall Scott M, Robinson B, Hills A, Buser GL, Salis K, Gargano J, Yoder J, Hill V, Buser GL, Salis K, Gargano J, Yoder J, Hill V, Xiao L, Roellig D, Hedberg K. 2016. Communitywide cryptosporidiosis outbreak associated with a surface water-supplied municipal water system-Baker City, Oregon, 2013. Epidemiology and Infection, 144, 274-284.

51. Di Giovanni GD, Lechevallier MW. 2005. QuantitativePCR assessment of Cryptosporidium parvum cell culture infection. Applied and Environmental Microbiology, 71, $1495-1500$.

52. Dibao-Dina A, Follet J, Ibrahim M, Vlandas A, Senez V. 2015. Electrical impedance sensor for quantitative monitoring of infection processes on HCT- 8 cells by the waterborne parasite Cryptosporidium. Biosensors and Bioelectronics, 66: 69-76.

53. Dubey JP 1998. Toxoplasma gondii oocyst survival under defined temperatures. Journal of Parasitology, 84, 862-865.

54. Dubey JP, Ferreira LR, Martins J, McLeod R. 2012. Oral oocyst-induced mouse model of toxoplasmosis: Effect of infection with Toxoplasma gondii strains of different genotypes, dose, and mouse strains (transgenic, out-bred, in-bred) on pathogenesis and mortality. Parasitology, 139, $1-13$.

55. Dubey JP, Jenkins MC, Thayer DW, Kwok OCH, Shen SK. 1996. Killing of Toxoplasma gondii oocysts by irradiation and protective immunity induced by vaccination with irradiated oocysts. Journal of Parasitology, 82, 724-727.

56. Dubey JP. 2009. Toxoplasmosis of animals and humans. CRC Press, Inc., Boca Raton.

57. Dubey JP. 2010. Toxoplasmosis of animals and humans, second ed. CRC Press, Boca Raton. (FL, USA).

58. Dumètre A, Dardé ML. 2003. How to detect Toxoplasma gondii oocysts in environmental samples? FEMS Microbiology Reviews, 27, 651-661.

59. Dumètre A, Le Bras C, Baffet M, Meneceur P, Dubey J-P., Derouin F, Duguet JP, Joyeux M, Moulin L. 2008. Effects of ozone and ultraviolet radiation treatments on the infectivity of Toxoplasma gondii oocysts. Veterinary Parasitology, 153, 209-213.

60. EFSA (European Food Safety Authority) and ECDC (European Centre for Disease Prevention and Control). 2017. The European Union summary report on trends and sources of zoonoses, zoonotic agents and food-borne outbreaks in 2016. EFSA Journal 2017, 15:5077.

61. Efstratiou A, Ongerth JE, Karanis P. 2017. Waterborne transmission of protozoan parasites: Review of worldwide outbreaks - An update 2011-2016. Water Research, 144, $14-22$.

62. El Zawawy LA, El-Said D, Ali SM, Fathy FM. 2010. Disinfection efficacy of sodium dichloroisocyanurate (NADCC) against common food-borne intestinal protozoa. Journal of the Egyptian Society of Parasitology, 40:165-168

63. Esmerini PO, Gennari SM, Pena HFJ. 2010. Analysis of marine bivalve shellfish from the fish market in Santos city, São Paulo state, Brazil, for Toxoplasma gondii. Veterinary Parasitology, 170, 8-13. 
64. Ethelberg S, Lisby M, Vestergaard LS, Enemark HL, Olsen KE, Stensvold CR, Nielsen HV, Porsbo LJ, Plesner AM, Mølbak K. 2009. A foodborne outbreak of Cryptosporidium hominis infection. Epidemiology \& Infection, 137, 348-356.

65. FAO/OMS. 1999. Principles and guidelines for the conduct of microbiological risk assessment. Codex Alimentarius Commission, CAC/GL 30-1999.

66. Fayer R, Leek RG. 1984. The effects of reducing conditions, medium, $\mathrm{pH}$, temperature, and time on in vitro excystation of Cryptosporidium. Journal of Protozoology, 31, 567-569.

67. Fayer R, Lewis EJ, Trout JM, Graczyk TK, Jenkins MC, Higgins J, Xiao L, Lal AA. 1999. Cryptosporidium parvum in oysters from commercial harvesting sites in the Chesapeake Bay. Emerging Infectious Diseases, 5, 706-710.

68. Fayer R, Trout JM, Jenkins MC. 1998. Infectivity of Cryptosporidium parvum oocysts stored in water at environmental temperatures. Journal of Parasitology, 84, 1165-1169.

69. Fayer R, Trout JM, Lewis EJ, Santin M, Zhou L, Lal AA, Xiao L. 2003. Contamination of Atlantic coast commercial shellfish with Cryptosporidium. Parasitology Research, $89,141-145$.

70. Fayer R, Trout JM, Lewis EJ, Xiao L, Lal AA, Jenkins MC, Graczyk TK. 2002. Temporal variability of Cryptosporidium in the Chesapeake Bay. Parasitology Research, 88, 998-1003.

71. FayerR, Graczyk TK, Lewis EJ, Trout JM, Farley CA. 1998. Survival of infectious Cryptosporidium parvum oocysts in seawater and eastern oysters (Crassostrea virginica) in the Chesapeake Bay. Applied and Environmental Microbiology, 64, 1070-1074.

72. Figgatt M, Mergen K, Kimelstein D, Mahoney DM, Newman A, Nicholas D, Ricupero K, Cafiero T, Corry D, Ade J, Kurpiel P, Madison-Antenucci S, Anand M. 2017. Giardiasis outbreak associated with asymptomatic food handlers in New York State, 2015. Journal of Food Protection, 12, 837-841.

73. Finch GR, Black EK, Gyürék L, Belosevic M. 1993. Ozone inactivation of Cryptosporidium parvum in demand-free phosphate buffer determined by in vitro excystation and animal infectivity. Applied and Environmental Microbiology, 59, 4203-4210.

74. Finch GR, Black EK, Labatiuk CW, Gyürék L, Belosevic M. 1993. Comparison of Giardia lamblia and Giardia muris cyst inactivation by ozone. Applied and Environmental Microbiology, 59, 3674-3680.

75. Fittipaldi M, Nocker A, Codony F. 2012. Progress in understanding preferential detection of live cells using viability dyes in combination with DNA amplification. Journal of Microbiological Methods, 91, 276-289.

76. Fontaine M. Guillot E. 2003. Study of $18 \mathrm{~S}$ rRNA and rDNA stability by real-time RT-PCR in heat-inactivated Cryptosporidium parvum oocysts. FEMS Microbiology Letters, 226, 237-243.

77. Fontán-Sainz M, Gómez-Couso H, Fernández-Ibáñez P Ares-Mazás E. 2012. Evaluation of the solar water disinfection process (SODIS) against Cryptosporidium parvum using a $25-\mathrm{L}$ static solar reactor fitted with a compound parabolic collector (CPC). American Journal of Tropical Medicine and Hygiene, 86, 223-228.

78. Freire-Santos F, Gómez-Couso H, Ortega-Iñarrea MR, Castro-Hermida JA, Oteiza-López AM, García-Martín O, Ares-Mazás ME. 2002. Survival of Cryptosporidium parvum oocysts recovered from experimentally contaminated oysters (Ostrea edulis) and clams (Tapes decussatus). Parasitology Research, 88, 130-133.
79. Freyre A, Falcón J. 2004. Massive excystation of Toxoplasma gondii sporozoites. Experimental Parasitology, 107: 72-7.

80. Füchslin HP, Kötzsch S, Egli T. 2012. Cryptosporidium spp. in drinking water. Samples from rural sites in Switzerland. Swiss Medical Weekly, 142, w13683.

81. Garcés-Sanchez G, Wilderer PA, Horn H, Munch J-C., Lebuhn M. 2013. Assessment of the viability of Cryptosporidium parvum oocysts with the induction ratio of hsp70 mRNA production in manure. Journal of Microbiological Methods, 94, 280-289.

82. Garcia A, Yanko W, Batzer G, Widmer G. 2002. Giardia cysts in tertiary-treated wastewater effluents: are they infective? Water Environment Research, 74, 541-544.

83. Garvey M, Farrell H, Cormican M, Rowan N. 2010. Investigations of the relationship between use of in vitro cell culture-quantitative PCR and a mouse-based bioassay for evaluating critical factors affecting the disinfection performance of pulsed UV light for treating Cryptosporidium parvum oocysts in saline. Journal of Microbiological Methods, 80, 267-273.

84. Garvey M, Stocca A, Rowan N. 2014. Development of a combined in vitro cell culture - quantitative PCR assay for evaluating the disinfection performance of pulsed light for treating the waterborne enteroparasite Giardia lamblia. Experimental Parasitology, 144, 6-13.

85. Gennaccaro AL, McLaughlin MR, Quintero-Betancourt W, Huffman DE, Rose JB. 2003. Infectious Cryptosporidium parvum oocysts in final reclaimed effluent. Applied and Environmental Microbiology, 69, 4983-4984.

86. Goater AD, Burt JPH, Pethig R. 1997. A combined travelling wave dielectrophoresis and electrorotation device: applied to the concentration and viability determination of Cryptosporidium. Journal of Physics D: Applied Physics, 30, L65.

87. Goater AD, Pethig R. 1999. Electrorotation and dielectrophoresis. Parasitology, 117, 177-189.

88. Gomez-Bautista M, Ortega-Mora LM, Tabares E, LopezRodas V, Costas E. 2000. Detection of infectious Cryptosporidium parvum oocysts in mussels (Mytilus galloprovincialis) and cockles (Cerastoderma edule). Applied and Environmental Microbiology, 66, 1866-1870.

89. Gómez-Couso H, Fontán-Sainz M, Fernández-Ibáñez P, Ares-Mazás E. 2012. Speeding up the solar water disinfection process (SODIS) against Cryptosporidium parvum by using 2 . 5L static solar reactors fitted with compound parabolic concentrators (CPCs). Acta Tropica, $124,235-242$

90. Gómez-Couso H, Freire-Santos F, Martínez-Urtaza J, García-Martín O, Ares-Mazás ME. 2003. Contamination of bivalve molluscs by Cryptosporidium oocysts: the need for new quality control standards. International Journal of Food Microbiology, 87, 97-105.

91. Gómez-Couso H, Méndez-Hermida F, Castro-Hermida JA, Ares-Mazás E. 2006. Cooking mussels (Mytilus galloprovincialis) by steam does not destroy the infectivity of Cryptosporidium parvum. Journal of Food Protection, 69, 948-950.

92. Graczyk TK, Grimes BH, Knight R, Da Silva AJ, Pieniazek NJ, Veal DA. 2003. Detection of Cryptosporidium parvum and Giardia lamblia carried by synanthropic flies by combined fluorescent in situ hybridization and a monoclonal antibody. American Journal of Tropical Medicine and Hygiene, 68, 228-232.

93. Graczyk TK, Lewis EJ, Glass G, Dasilva AJ, Tamang L, Girouard AS, Curriero FC. 2007. Quantitative assessment of viable Cryptosporidium parvum load in commercial 
oysters (Crassostrea virginica) in the Chesapeake Bay. Parasitology Research, 100, 247-253.

94. Griffiths JK, Theodos C, Paris M, Tzipori S. 1998. The gamma interferon gene knockout mouse: a highly sensitive model for evaluation of therapeutic agents against Cryptosporidium parvum. Journal of Clinical Microbiology, 36, 2503-2508.

95. Guzman-Herrador B, Carlander A, Ethelberg S, Freiesleben de Blasio B, Kuusi M, Lund V, Löfdahl M, MacDonald E, Nichols G, Schönning C, Sudre B, Trönnberg L, Vold L, Semenza J C, Nygård K. 2015. Waterborne outbreaks in the Nordic countries, 1998 to 2012. Euro Surveillance, 20:pii $=21160$.

96. Habtewold T, Groom Z, Duchateau L, Christophides GK. 2015. Detection of viable Plasmodium ookinetes in the midguts of Anopheles coluzzi using PMA-qrtPCR. Parasites \& Vectors, 8, 455.

97. Hallier-Soulier S, Guillot E. 2003. An immunomagnetic separation-reverse transcription polymerase chain reaction (IMS-RT-PCR) test for sensitive and rapid detection of viable waterborne Cryptosporidium parvum. Environmental Microbiology, 5, 592-598.

98. Hanes DE, Worobo RW, Orlandi PA, Burr DH, Miliotis MD, Robl MG, Bier JW, Arrowood MJ, Churey JJ, Jackson GJ. 2002. Inactivation of Cryptosporidium parvum oocysts in fresh apple cider by UV irradiation. Applied and Environmental Microbiology, 68, 4168-4172.

99. Harp JA, Fayer R, Pesch BA, Jackson GJ. 1996. Effect of pasteurization on infectivity of Cryptosporidium parvum oocysts in water and milk. Applied and Environmental Microbiology, 62, 2866-2868.

100. Hautus MA, Kortbeek LM, Vetter JC, Laarman JJ. 1988. In vitro excystation and subsequent axenic growth of Giardia lamblia. Transactions of the Royal Society of Tropical Medicine and Hygiene. 82, 858-861.

101. Healey MC, Yang S, Du C, Liao SF. 1997. Bovine fallopian tube epithelial cells, adult C57BL $/ 6$ mice, and nonneonatal pigs as models for cryptosporidiosis. Journal of Eukaryotic Microbiology, 44, 64S-65S.

102. Hijjawi NS, Meloni BP, Ng'anzo M, Ryan UM, Olson ME, Cox PT, Monis PT, Thompson RCA. 2004. Complete development of Cryptosporidium parvum in host cell-free culture. International Journal for Parasitology, 34, 769-777.

103. Hikosaka K, Satoh M, Koyama Y, Nakai Y. 2005. Quantification of the infectivity of Cryptosporidium parvum by monitoring the oocyst discharge from SCID mice. Veterinary Parasitology, 134, 173-176.

104. Hohweyer J, Cazeaux C, Travaillé E, Languet E, Dumètre A, Aubert D, Terryn C, Dubey JP, Azas N, Houssin M, Favennec L, Villena I, La Carbona S. 2016. Simultaneous detection of the protozoan parasites Toxoplasma, Cryptosporidium and Giardia in food matrices and their persistence on basil leaves. Food Microbiology, 57, 36-44.

105. Hong S, Kim K, Yoon S, Park WY, Sim S, Yu JR. 2014. Detection of Cryptosporidium parvum in environmental soil and vegetables. Journal of Korean Medical Science, 29, $1367-1371$.

106. Hønsvall BK, Robertson LJ, 2017. From research lab to standard environmental analysis tool: will NASBA make the leap? Water Research, 109, 389-397.

107. Hønsvall BK, Robertson LJ. 2017. Real-time nucleic acid sequence-based amplification (NASBA) assay targeting MIC1 for detection of Cryptosporidium parvum and Cryptosporidium hominis oocysts. Experimental Parasitology, 172, 61-67.

108. Hou L, Li X, Dunbar L, Moeller R, Palermo B, Atwil ER. 2004. Neonatal-mouse infectivity of intact Cryptosporidium parvum oocysts isolated after optimized in vitro excystation. Applied and Environmental Microbiology, 70, 642-646.

109. Huffman DE, Gennaccaro AL, Berg TL, Batzer G, Widmer G. 2006. Detection of infectious parasites in reclaimed water. Water Environment Research, 79, 2297-2302.

110. Isaac-Renton J, Bowie WR, King A, Irwin GS, Ong CS, Fung CP, Shokeir MO, Dubey JP. 1998. Detection of Toxoplasma gondii oocysts in drinking water. Applied and Environmental Microbiology, 64, 2278-2280.

111. Isaac-Renton J, Moorehead W, Ross A. 1996. Longitudinal studies of Giardia contamination in two community drinking water supplies: cyst levels, parasite viability, and health impact. Applied and Environmental Microbiology, $62,47-54$

112. ISO 18744:2016. Microbiology of the food chain Detection and enumeration of Cryptosporidium and Giardia in fresh leafy green vegetables and berry fruits.

113. Iturriaga R, Zhang S, Sonek GJ, Stibbs H. 2001. Detection of respiratory enzyme activity in Giardia cysts and Cryptosporidium oocysts using redox dyes and immunofluorescence techniques. Journal of Microbiological Methods, $46,19-28$.

114. Jenkins M, Trout J, Abrahamsen MS, Lancto CA, Higgins J, Fayer R. 2000. Estimating viability of Cryptosporidium parvum oocysts using reverse transcriptase polymerase chain reaction (RT-PCR) directed at mRNA encoding amyloglucosidase. Journal of Microbiological Methods. 43, 97-106.

115. Jenkins M, Trout J, Higgins J, Dorsch M, Veal D, Fayer R. 2003. Comparison of tests for viable and infectious Cryptosporidium parvum oocysts. Parasitology Research, 89, $1-5$.

116. Jenkins MB, Anguish LJ, Bowman DD, Walker MJ, Ghiorse WC. 1997. Assessment of a dye permeability assay for determination of inactivation rates of Cryptosporidium parvum oocysts. Applied and Environmental Microbiology, 63, 3844-3850.

117. Johnson AM, Di Giovanni GD, Rochelle PA. 2012. Comparison of assays for sensitive and reproducible detection of cell culture-infectious Cryptosporidium parvum and Cryptosporidium hominis in drinking water. Applied and Environmental Microbiology, 78, 156-162.

118. Johnson AM, Linden K, Ciociola KM, De Leon R, Widmer G, Rochelle PA. 2005. UV inactivation of Cryptosporidium hominis as measured in cell culture. Applied and Environmental Microbiology, 71, 2800-2802.

119. Johnson LL. 1992. SCID mouse models of acute and relapsing chronic Toxoplasma gondii infections. Infection and Immunity, 60, 3719-3724.

120. Jones JL, Dubey JP. 2010. Waterborne toxoplasmosis Recent developments. Experimental Parasitology, 124, 10-25.

121. Kato S, Jenkins MB, Fogarty EA, Bowman DD. 2002. Effects of freeze-thaw events on the viability of Cryptosporidium parvum oocysts in soil. Journal of Parasitology, 88, 718-722.

122. Keegan AR, Fanok S, Monis PT, Saint CP. 2003. Cell culture-taqman PCR assay for evaluation of Cryptosporidium parvum disinfection. Applied and Environmental Microbiology, 69, 2505-2511.

123. King BJ, Hoefel D, Daminato DP, Fanok S, Monis PT. 2008. Solar UV reduces Cryptosporidium parvum oocyst infectivity in environmental waters. Journal of Applied Microbiology, 104, 1311-1323.

124. King BJ, Keegan AR, Phillips R, Fanok S, Monis PT, 2012. Dissection of the hierarchy and synergism of the bile derived signal on Cryptosporidium parvum excystation and infectivity. Parasitology, 139, 1533-1546. 
125. King BJ, Keegan AR, Robinson BS, Monis PT. 2011. Cryptosporidium cell culture infectivity assay design. Parasitology, 138, 671-681.

126. Kniel KE, Lindsay DS, Sumner SS, Hackney CR, Pierson MD, Dubey JP. 2002. Examination of attachment and survival of Toxoplasma gondii oocysts on raspberries and blueberries. Journal of Parasitology, 88, 790-793.

127. Kniel KE, Sumner SS, Lindsay DS, Hackney CR, Pierson MD, Zajac AM, Golden DA, Fayer R. 2003. Effect of organic acids and hydrogen peroxide on Cryptosporidium parvum viability in fruit juices. Journal of Food Protection, 66, 1650-1657.

128. Korich DG, Marshall MM, Smith HV, O'Grady J, Bukhari Z, Fricker CR, Rosen JP, Clancy JL. 2000. Interlaboratory comparison of the CD-I neonatal mouse logistic dose-response model for Cryptosporidium parvum oocysts. Journal of Eukaryotic Microbiology, 47, 294-298.

129. Korich DG, Mead JR, Madore MS, Sinclair NA, Sterling CR. 1990. Effects of ozone, chlorine dioxide, chlorine, and monochloramine on Cryptosporidium parvum oocyst viability. Applied and Environmental Microbiology, 56, 1423-1428.

130. Kotloff KL, Nataro JP, Blackwelder WC, Nasrin D, Farag TH, Panchalingam S, Wu Y, Sow SO, Sur D, Breiman RF, Faruque AS, Zaidi AKM, Saha D, Alonso PL, Tamboura B, Sanogo D, Onwuchekwa U, Manna B, Ramamurthy T, Kanungo S, Ochieng JB, Omore R, Oundo JO, Hossain A, Das SK, Ahmed S, Qureshi S, Quadri F, Adegbola RA, Antonio M, Hossain MJ, Akinsola A, Mandomando I, Nhampossa T, Acácio S, Biswas K, O'Reilly CE, Mintz ED, Berkeley LY, Muhsen K, Sommerfelt H, RobinsBrowne RM, Levine MM. 2013. Burden and aetiology of diarrhoeal disease in infants and young children in developing countries (the Global Enteric Multicenter Study, GEMS): a prospective, case-control study. Lancet, $382,209-222$

131. Le Goff L, Hubert B, Favennec L, Villena I, Ballet JJ, Agoulon A, Orange N, Gargala G. 2015. Pilot-scale pulsed UV light irradiation of experimentally infected raspberries suppresses Cryptosporidium parvum infectivity in immunocompetent suckling mice. Journal of Food Protection, $78,2247-2252$.

132. Lebbad M, Mattsson JG, Christensson B, Ljungström B, Backhans A. Andersson JO, Svärd SG. 2010. From mouse to moose: multilocus genotyping of Giardia isolates from various animal species. Veterinary Parasitology, 168, 231-239.

133. LeChevallier MW, Di Giovanni GD, Clancy JL, Bukhari Z, Bukhari S, Rosan JS, Sobrinho J, Frey MM. 2003. Comparison of method 1623 and cell culture-PCR for detection of Cryptosporidium spp in source waters. Applied and Environmental Microbiology, 69, 971-979.

134. Lee GC, Nam SH, Chae JC, Lee CH. 2009. Giardia duodenalis: improved detection of viable cysts by reverse transcription-PCR of heat shock-inducible hsp 70 gene. Experimental Parasitology, 123, 377-380.

135. Lee S-U., Joung M, Ahn M-H., Huh S, Song H, Park W-Y., Yu J-R. 2008. CP2 gene as a useful viability marker for Cryptosporidium parvum. Parasitology Research, 102, 381-387.

136. Lélu M, Villena I, Dardé ML, Aubert D, Geers R, Dupuis E, Marnef F, Poulle ML, Gotteland C, Dumètre A, GilotFromont E. 2012. Quantitative estimation of the viability of Toxoplasma gondii oocysts in soil. Applied and Environmental Microbiology, 78, 5127-5132.

137. Lemée V, Zaharia I, Nevez G, Rabodonirina M, Brasseur P, Ballet JJ, Favennec L. 2000. Metronidazole and albendazole susceptibility of 11 clinical isolates of Giardia duodenalis from France. Journal of Antimicrobial Chemotherapy, 46, 819-821.

138. Lemos V, Graczyk TK, Alves M, Lobo ML, Sousa MC, Antunes F, Matos O. 2005. Identification and determination of the viability of Giardia lamblia cysts and Cryptosporidium parvum and Cryptosporidium hominis oocysts in human fecal and water supply samples by fluorescent in situ hybridization (FISH) and monoclonal antibodies. Parasitology Research, 98, 48-53.

139. Li D, Craik SA, Smith DW, Belosevic M. 2007. Comparison of levels of inactivation of two isolates of Giardia lamblia cysts by UV light. Applied and Environmental Microbiology, 73, 2218-2223.

140. Li D, Craik SA, Smith DW, Belosevic M. 2009. Infectivity of Giardia lamblia cysts obtained from wastewater treated with ultraviolet light. Water Research, 43, 3137-3146.

141. Li H, Gyürék LL, Finch GR, Smith DW, Belosevic M. 2001. Effect of temperature on ozone inactivation of Cryptosporidium parvum in oxidant demand-free phosphate buffer. Journal of Environmental Engineering, 127, 456-467.

142. Li X, Brasseur P, Agnamey P, Ballet JJ, Clemenceau C. 2004. Time and temperature effects on the viability and infectivity of Cryptosporidium parvum oocysts in chlorinated tap water. Archives of Environmental Health, 59, $462-466$.

143. Li X, Guyot K, Dei-Cas E, Mallard JP, Ballet JJ, Brasseur P. 2006. Cryptosporidium oocysts in mussels (Mytilus edulis) from Normandy (France). International Journal of Food Microbiology, 108, 321-325.

144. Liang Z, Keeley A. 2012. Comparison of propidium monoazide-quantitative PCR and reverse transcription quantitative PCR for viability detection of fresh Cryptosporidium oocysts following disinfection and after longterm storage in water samples. Water Research, 46, 59415953.

145. Lindsay DS, Collins MV, Jordan CN, Flick GJ, Dubey JP. 2005. Effects of high pressure processing on infectivity of Toxoplasma gondii oocysts for mice. Journal of Parasitology, 91, 699-701.

146. Lindsay DS, Holliman D, Flick GJ, Goodwin DG, Mitchell SM, Dubey JP. 2008. Effects of high pressure processing on Toxoplasma gondii oocysts on raspberries. Journal of Parasitology, 94, 757-758.

147. Lonigro A, Pollice A, Spinelli R, Berrilli F, Di Cave D, D'Orazi C, Cavallo P, Brandonisio O. 2006. Giardia cysts and Cryptosporidium oocysts in membrane-filtered municipal wastewater used for irrigation. Applied and Environmental Microbiology, 72, 7916-7918.

148. Lorenzo-Lorenzo MJ, Ares-Mazas ME, Villacorta-Martinez de Maturana I, Duran-Oreiro D. 1993. Effect of ultraviolet disinfection of drinking water on the viability of Cryptosporidium parvum oocysts. Journal of Parasitology, 79, 67-70.

149. Ma J, Feng Y, Hu Y, Villegas EN, Xiao L. 2016. Human infective potential of Cryptosporidium spp., Giardia duodenalis and Enterocytozoon bieneusi in urban wastewater treatment plant effluents. Journal of Water and Health, 14, 411-423.

150. Macarisin D, Santín M, Bauchan G, Fayer R. 2010. Infectivity of Cryptosporidium parvum oocysts after storage of experimentally contaminated apples. Journal of Food Protection, 73, 1824-1829.

151. Marchioro AA, Tiyo BT, Colli CM, de Souza CZ, Garcia JL, Gomes ML, Falavigna-Guilherme AL. 2016. First detection of Toxoplasma gondii DNA in the fresh leafs of vegetables in South America. Vector Borne and Zoonotic Diseases, 16, 624-626. 
152. Matsubayashi M, Ando H, Kimata I, Nakagawa H, Furuya M, Tani H, Sasai K. 2010. Morphological changes and viability of Cryptosporidium parvum sporozoites after excystation in cell-free culture media. Parasitology, 137, 1861-1866.

153. McGrath JS, Quist J, Seddon JRT, Lai SCS, Lemay SG, Bridle HL. 2016. Deformability assessment of waterborne protozoa using a microfluidic-enabled force microscopy Probe. PLoS One 11, e0150438.

154. McGuigan KG, Méndez-Hermida F, Castro-Hermida JA, Ares- Mazás E, Kehoe SC, Boyle M, Sichel C, FernándezIbáñez P, Meyer BP, Ramalingham S, Meyer EA. 2006. Batch solar disinfection inactivates oocysts of Cryptosporidium parvum and cysts of Giardia muris in drinking water. Journal of Applied Microbiology, 101, 453-463.

155. McKerr C, Adak GK, Nichols G, Gorton R, Chalmers RM, Kafatos G, Cosford P, Charlett A, Reacher M, Pollock KG, Alexander CL, Morton S. 2015. An outbreak of Cryptosporidium parvum across England \& Scotland associated with consumption of fresh pre-cut salad leaves, May 2012. PLoS One, 10, e0125955.

156. Mead JR, Ilksoy N, You X, Belenkaya Y, Arrowood MJ, Fallon MT, Schinazi RF. 1994. Infection dynamics and clinical features of cryptosporidiosis in SCID mice. Infection and Immunity, 62, 1691-1695.

157. Melicherová J, Mazourová V, Valigurová A. 2016. In vitro excystation of Cryptosporidium muris oocysts and viability of released sporozoites in different incubation media. Parasitology Research, 115, 1113-1121.

158. Méndez-Hermida F, Castro-Hermida JA, Ares-Mazás E, Kehoe SC, McGuigan KG. 2005. Effect of batch-process solar disinfection on survival of Cryptosporidium parvum oocysts in drinking water. Applied and Environmental Microbiology, 71, 1653-1654.

159. Miller CN, Jossé L, Brown I, Blakeman B, Povey J, Yiangou L, Price M, Cinatl J Jr, Xue WF, Michaelis M, Tsaousis AD. 2017. A cell culture platform for Cryptosporidium that enables long-term cultivation and new tools for the systematic investigation of its biology. doi: 10.1016/j.ijpara.2017.10.001

160. Moore AG, Vesey G, Champion A, Scandizzo P, Deere D, Veal D, Williams KL. 1998. Viable Cryptosporidium parvum oocysts exposed to chlorine or other oxidising conditions may lack identifying epitopes. International Journal of Parasitology, 28, 1205-1212.

161. Moreno Y, Moreno-Mesonero L, Amorós I, Pérez R, Morillo JA, Alonso JL. 2018. Multiple identification of most important waterborne protozoa in surface water used for irrigation purposes by $18 \mathrm{~S}$ rRNA amplicon-based metagenomics. International Journal of Hygiene and Environmental Health, 221, 102-111.

162. Mtapuri-Zinyowera S, Midzi N, Muchaneta-Kubara CE, Simbini T, Mduluza T. 2009. Impact of solar radiation in disinfecting drinking water contaminated with Giardia duodenalis and Entamoeba histolytica/dispar at a pointof-use water treatment. Journal of Applied Microbiology, $106,847-852$.

163. Nam S, Lee G. 2010. A new duplex reverse transcription PCR for simultaneous detection of viable Cryptosporidium parvum oocysts and Giardia duodenalis cysts. Biomedical and Environmental Sciences, 23, 146-150.

164. Nebe-von-Caron G, Stephens PJ, Hewitt CJ, Powell JR, Badley RA. 2000. Analysis of bacterial function by multicolour fluorescence flow cytometry and single cell sorting. Journal of Microbiological Methods, 42, 97-114.

165. Neumann NF, Gyürek LL, Gammie L, Finch GR, Belosevic M. 2000. Comparison of animal infectivity and nucleic acid staining for assessment of Cryptosporidium parvum viability in water. Applied and Environmental Microbiology, 66, 406-412.

166. Nichols RA, Paton CA, Smith HV. 2004. Survival of Cryptosporidium parvum oocysts after prolonged exposure to still natural mineral waters. Journal of Food Protection, 67, 517-523.

167. Nichols RAB, Connelly L, Sullivan CB, Smith HV. 2010. Identification of Cryptosporidium species and genotypes in Scottish raw and drinking waters during a one-year monitoring period. Applied and Environmental Microbiology, 76, 5977-5986.

168. Nocker A, Cheung C-Y., Camper AK. 2006. Comparison of propidium monoazide with ethidium monoazide for differentiation of live vs. dead bacteria by selective removal of DNA from dead cells. Journal of Microbiological Methods, 67, 310-320.

169. Novak SM, Sterling CR. 1991. Susceptibility dynamics in neonatal BALB/c mice infected with Cryptosporidium parvum. Journal of Protozoology, 38, 103S-104S.

170. Okhuysen PC, Chappell CL, Crabb JH, Sterling CR, DuPont HL. 1999. Virulence of three distinct Cryptosporidium parvum isolates for healthy adults. Journal of Infectious Diseases, 180, 1275-1281.

171. Opsteegh M, et al. 2016. Relationship between seroprevalence in the main livestock species and presence of Toxoplasma gondii in meat (GP/EFSA/BIOHAZ/2013/ 01): an extensive literature review. Final report. EFSA supporting publication 2016:EN-996, $294 \mathrm{pp}$.

172. Oyane I, Furuta M, Stavarache CE, Hashiba K, Mukai S, Nakanishi JM, Kimata I, Maeda Y. 2005. Inactivation of Cryptosporidium parvum by ultrasonic irradiation. Environmental Science \& Technology, 39, 7294-7298.

173. Paziewska-Harris A, Schoone G, Schallig HDFH. 2016. An easy 'one tube' method to estimate viability of Cryptosporidium oocysts using real-time qPCR. Parasitology Research, 115, 2873-2877.

174. Peng MM, Xiao L, Freeman AR, Arrowood MJ, Escalante AA, Weltman AC, Ong CSL, Mac Kenzie WR, Lal AA, Beard CB. 1997. Genetic polymorphism among Cryptosporidium parvum isolates: evidence of two distinct human transmission cycles. Emerging Infectious Diseases, 3, 567-573

175. Pönka A, Kotilainen H, Rimhanen-Finne R, Hokkanen P, Hänninen ML, Kaarna A, Meri T, Kuusi M. 2009. A foodborne outbreak due to Cryptosporidium parvum in Helsinki, November 2008. Eurosurveillance, 14, pii: 19269.

176. Quilez J, Sanchez-Acedo C, Avendaño C, del Cacho E, Lopez-Bernad F. 2005. Efficacy of two peroxygen-based disinfectants for inactivation of Cryptosporidium parvum oocysts. Applied and Environmental Microbiology, 71, 2479-2483.

177. Rasmussen KR, Healey MC. 1992. Experimental Cryptosporidium parvum infections in immunosuppressed adult mice. Infection and Immunity, 60, 1648-1652.

178. Reduker DW, Speer CA. 1985. Factors influencing excystation in Cryptosporidium oocysts from cattle. Journal of Parasitology. 71, 112-115.

179. Rehg JE, Hancock ML, Woodmansee DB. 1987. Characterization of cyclophosphamide-rat model of cryptosporidiosis. Infection and Immunity, 55, 2669-2674.

180. Rendtorff RC. 1979. The experimental transmission of Giardia lamblia among volunteer subjects. Waterborne transmission of Giardiasis Proceeding of a Symposium, Cincinnati, USA.

181. Rice E, Schaefer EW. 1981. Improved in vitro excystation procedure for Giardia lamblia. Journal of Clinical Microbiology, 14: 709-710. 
182. Robert-Gangneux F, Dardé ML. 2012. Epidemiology of and diagnostic strategies for toxoplasmosis. Clinical Microbiology Reviews, 25:264-96.

183. Robertson LJ, Campbell AT, Smith HV. 1992. Survival of Cryptosporidium parvum oocysts under various environmental pressures. Applied and Environmental Microbiology, 58, 3494-3500.

184. Robertson LJ, Campbell AT, Smith HV. 1993. In vitro excystation of Cryptosporidium parvum. Parasitology, 106: 13-9.

185. Robertson LJ, Gjerde BK. 2007. Cryptosporidium oocysts: challenging adversaries? Trends in Parasitology, 23, 344-347.

186. Rochelle PA, Fallar D, Marshall MM, Montelone BA, Upton SJ, Woods K. 2004. Irreversible UV inactivation of Cryptosporidium spp. despite the presence of UV repair genes. Journal of Eukaryotic Microbiology, 51, 553-562.

187. Rochelle PA, Marshall MM, Mead JR, Johnson AM, Korish DG, Rosen JS, De Leon R. 2002. Comparison of in vitro cell culture and a mouse assay for measuring infectivity of Cryptosporidium parvum. Applied and Environmental Microbiology, 68, 3809-3817.

188. Rossi P, Pozio E, Besse MG, Gomez Morales MA, La Rosa G. 1990. Experimental cryptosporidiosis in hamsters. Journal of Clinical Microbiology, 28, 356-357.

189. Rotman B, Papermaster BW. 1966. Membrane properties of living mammalian cells as studied by enzymatic hydrolysis of fluorogenic esters. Proceedings of the National Academy of Sciences of the United States, 55, 134-141.

190. Schets FM, Engels GB, During M, De Roda Husman AM. 2005. Detection of infectious Cryptosporidium oocysts by cell culture immunofluorescence assay: applicability to environmental samples. Applied and Environmental Microbiology, 71, 6793-6798.

191. Schets FM, van den Berg HHJL, Engels GB, Lodder WJ, de Roda Husman AM. 2007. Cryptosporidium and Giardia in commercial and non-commercial oysters (Crassostrea gigas) and water from the Oosterschelde, the Netherlands. International Journal of Food Microbiology, 113, 189-194.

192. Schupp DG, Erlandsen SL. 1987. A new method to determine Giardia cyst viability: correlation of fluorescein diacetate and propidium iodide staining with animal infectivity. Applied and Environmental Microbiology, 53, 704-707.

193. Shahiduzzaman M, Dyachenko V, Keidel J, Schmäschke R, Daugschies A. 2010. Combination of cell culture and quantitative PCR (cc-qPCR) to assess disinfectants efficacy on Cryptosporidium oocysts under standardized conditions. Veterinary Parasitology, 167, 43-49.

194. Sherwood D, Angus KW, Snodgrass DR, Tzipori S. 1982. Experimental cryptosporidiosis in laboratory mice. Infection and Immunity, 38, 471-475.

195. Shin GA, Linden KG, Arrowood MJ, Sobsey MD. 2001. Low-pressure UV inactivation and DNA repair potential of Cryptosporidium parvum oocysts. Applied and Environmental Microbiology, 67, 3029-3032.

196. Shin GA, Linden KG, Faubert G. 2009. Inactivation of Giardia lamblia cysts by polychromatic UV. Letters in Applied Microbiology, 48, 790-792 (2009).

197. Slifko TR, Friedman D, Rose JB, Jakubowski W. 1997. An in vitro method for detecting infectious Cryptosporidium oocysts with cell culture. Applied and Environmental Microbiology, 63, 3669-3675.

198. Slifko TR, Huffman DE, Dussert B, Owens JH, Jakubowski W, Haas CN, Rose JB. 2002. Comparison of tissue culture and animal models for assessment of Cryptosporidium parvum infection. Experimental Parasitology, 101, 97-106.
199. Smith AL, Smith HV. 1989. A comparison of fluorescein diacetate and propidium iodide staining and in vitro excystation for determining Giardia intestinalis cyst viability. Parasitology, 99, 329-331.

200. Smith JJ, Gunasekera TS, Barardi CRM, Veal D, Vesey G. 2004. Determination of Cryptosporidium parvum oocyst viability by fluorescence in situ hybridization using a ribosomal RNA-directed probe. Journal of Applied Microbiology, 96, 409-417.

201. Smith JL. 1993. Documented Outbreaks of Toxoplasmosis: Transmission of Toxoplasma gondii to Human. Journal of Food Protection, 56, 630-639.

202. Strober W. 2015. Trypan blue exclusion test of cell viability. Current Protocols in Immunology, 111: A3.B.1-3.

203. Sundermann CA, Estridge BH. 2009. Inactivation of Giardia lamblia cysts by cobalt-60 irradiation. Journal of Parasitology, 96, 425-428.

204. Teunis PF, Chappell CL, Okhuysen PC. 2002. Cryptosporidium dose response studies: variation between isolates. Risk Analysis, 22, 175-183.

205. Thompson RCA, Olson ME, Zhu G, Enomoto S, Abrahamsen MS, Hijjawi NS. 2005. Cryptosporidium and cryptosporidiosis. Advances in Parasitology, 59, $77-158$.

206. Thompson RCA. 2004. The zoonotic significance and molecular epidemiology of Giardia and Giardiasis. Veterinary Parasitology, 126, 15-35.

207. Thurston-Enriquez JA, Watt P, Dowd SE, Enriquez R, Pepper IL, Gerba CP. 2002. Detection of protozoan parasites and microsporidia in irrigation waters used for crop production. Journal of Food Protection, 65, 378-382.

208. Tomonaga T, Rai SK, Uga S 2016. Differentiation between viable and dead Cryptosporidium oocysts using fluorochrome staining. Kobe Journal of Medical Sciences, 61:E138-E144.

209. Travaillé E, La Carbona S, Gargala G, Aubert D, Guyot K, Dumètre A, Villena I, Houssin M. 2016. Development of a qRT-PCR method to assess the viability of Giardia intestinalis cysts, Cryptosporidium spp. and Toxoplasma gondii oocysts. Food Control, 59, 359-365.

210. Tsushima Y, Karanis P, Kamada T, Xuan X, Makala LH, Tohya Y, Akashi H, Nagasawa H. 2003. Viability and infectivity of Cryptosporidium parvum oocysts detected in river water in Hokkaido, Japan. Journal of Veterinary Medical Science, 65, 585-589.

211. Tysnes KR, Robertson LJ. 2016. Establishment of caninederived Giardia duodenalis isolates in culture. Journal of Parasitology, 102:342-8.

212. Tzipori S, Rand W, Theodos C. 1995. Evaluation of a two-phase scid mouse model preconditioned with antiinterferon-gamma monoclonal antibody for drug testing against Cryptosporidium parvum. Journal of Infectious Diseases, 172, 1160-1164

213. Upton SJ, Tilley M, Brillhart DB. 1995. Effects of select medium supplements on in vitro development of Cryptosporidium parvum in HCT-8 cells. Journal of Clinical Microbiology, 33, 371-375.

214. Upton SJ, Tilley M, Brillhart DB. 1994. Comparative development of Cryptosporidium parvum (Apicomplexa) in 11 continuous host cell lines. FEMS Microbiology Letters, 118, 233-236

215. Utaaker KS, Skjerve E, Robertson LJ. 2017. Keeping it cool: Survival of Giardia cysts and Cryptosporidium oocysts on lettuce leaves. International Journal of Food Microbiology, 255, 51-57.

216. Varughese EA, Bennett-Stamper CL, Wymer LJ, Yadav JS. 2014. A new in vitro model using small intestinal 
epithelial cells to enhance infection of Cryptosporidium parvum. Journal of Microbiological Methods, 106, 47-54.

217. Vesey G, Ashbolt N, Fricker EJ, Deere D, Williams KL, Veal DA, Dorsch M. 1998. The use of a ribosomal RNA targeted oligonucleotide probe for fluorescent labelling of viable Cryptosporidium parvum oocysts. Journal of Applied Microbiology, 85, 429-440.

218. Villegas EN, Augustine SAJ, Villegas LF, Ware MW, See MJ, Lindquist HDA, Schaefer III FW, Dubey JP. 2010. Using quantitative reverse transcriptase PCR and cell culture plaque assays to determine resistance of Toxoplasma gondii oocysts to chemical sanitizers. Journal of Microbiological Methods, 81, 219-225.

219. Villena I, Aubert D, Gomis P, Ferté H, Inglard J-C., Denis-Bisiaux H, Dondon J-M., Pisano E, Ortis N, Pinon J-M. 2004. Evaluation of a strategy for Toxoplasma gondii oocyst detection in water. Applied and Environmental Microbiology, 70, 4035-4039.

220. Wainwright KE, Lagunas-Solar M, Miller MA, Barr BC, Gardner IA, Pina C, Melli AC, Packham AE, Zeng N, Truong T, Conrad PA. 2007. Physical inactivation of Toxoplasma gondii oocysts in water. Applied and Environmental Microbiology, 73, 5663-5666.

221. Wainwright KE, Lagunas-Solar M, Miller MA, Barr BC, Melli AC, Packham AE, Zeng N, Truong T, Conrad PA. 2010. Radiofrequency-induced thermal inactivation of Toxoplasma gondii oocysts in water. Zoonoses Public Health, 57, 74-81.

222. Wainwright KE, Miller MA, Barr BC, Gardner IA, Melli AC, Essert T, Packham AE, Truong T, Lagunas-Solar M, Conrad PA. 2007. Chemical inactivation of Toxoplasma gondii oocysts in water. Journal of Parasitology, 93, 925-931.

223. Ware MW, Augustine SAJ, Erisman DO, See MJ, Wymer L, Hayes SL, Dubey JP, Villegas EN. 2010. Determining UV inactivation of Toxoplasma gondii oocysts by using cell culture and a mouse bioassay. Applied and Environmental Microbiology, 76, 5140-5147.

224. Widmer G, Akiyoshi D, Buckholt MA, Feng X, Rich SM, Deary KM, Bowman CA, Xu P, Wang Y, Wang X, Buck GA, Tzipori S. 2000. Animal propagation and genomic survey of a genotype 1 isolate of Cryptosporidium parvum. Molecular and Biochemical Parasitology, 108:187-197.

225. Widmer G, Corey EA, Stein B, Griffiths JK, Tzipori S. 2000. Host cell apoptosis impairs Cryptosporidium parvum development in vitro. Journal of Parasitology, 86:922-928.

226. Widmer G, Orbacz EA, Tzipori S. 1999. $\beta$-Tubulin mRNA as a marker of Cryptosporidium parvum oocyst viability. Applied and Environmental Microbiology, 65, 1584-1588.

227. Xunde LI, Brasseur P. 2000. A NMRI suckling mouse model for the evaluation of infectivity of Cryptosporidium parvum oocysts. Chinese Journal of Parasitology and Parasitic Diseases, 18, 94-96.

228. Yang S, Benson SK, Du C, Healey MC. 2000. Infection of immunosuppressed C57BL $/ 6 \mathrm{~N}$ adult mice with a single oocyst of Cryptosporidium parvum. Journal of Parasitology, $86,884-887$.

229. Yielding LW, Yielding KL, Donoghue JE. 1984. Ethidium binding to deoxyribonucleic acid: spectrophotometric analysis of analogs with amino, azido, and hydrogen substituents. Biopolymers, 23, 83-110.

230. You X, Mead JR. 1988. Characterization of experimental Cryptosporidium parvum infection in IFN-gamma knockout mice. Parasitology, 117, 525-531.

231. Zeng D, Chen Z, Jiang Y, Xue F, Li B. 2016. Advances and Challenges in Viability Detection of Foodborne Pathogens. Frontiers in Microbiology, 7, 1833.

232. Zhao Z, Wang R, Zhao W, Qi M, Zhao J, Zhang L, Li J, Liu A. 2015. Genotyping and subtyping of Giardia and Cryptosporidium isolates from commensal rodents in China. Parasitology, 142, 800-806.

Cite this article as: Rousseau A, La Carbona S, Dumètre A, Robertson LJ, Gargala G, Escotte-Binet S, Favennec L, Villena I, Gérard C, Aubert D. 2018. Assessing viability and infectivity of foodborne and waterborne stages (cysts/oocysts) of Giardia duodenalis, Cryptosporidium spp., and Toxoplasma gondii: a review of methods. Parasite 25, 14

\section{PARASTE}

Reviews, articles and short notes may be submitted. Fields include, but are not limited to: general, medical and veterinary parasitology; morphology, including ultrastructure; parasite systematics, including entomology, acarology, helminthology and protistology, and molecular analyses; molecular biology and biochemistry; immunology of parasitic diseases; host-parasite relationships; ecology and life history of parasites; epidemiology; therapeutics; new diagnostic tools.

All papers in Parasite are published in English. Manuscripts should have a broad interest and must not have been published or submitted elsewhere. No limit is imposed on the length of manuscripts.

Parasite (open-access) continues Parasite (print and online editions, 1994-2012) and Annales de Parasitologie Humaine et Comparée (1923-1993) and is the official journal of the Société Française de Parasitologie. 